Article

\title{
Impacts of Large-Scale Groundwater Exploitation Based on Long-Term Evolution of Hydraulic Heads in Dhaka City, Bangladesh
}

\author{
Mazeda Islam ${ }^{1,2, *}$, Marc Van Camp ${ }^{1} \mathbb{D}$, Delwar Hossain ${ }^{2}$, Md. Mizanur Rahman Sarker ${ }^{1,2} \mathbb{D}$, Shahina Khatun $^{3}$ \\ and Kristine Walraevens ${ }^{1}$ (D) \\ 1 Laboratory for Applied Geology and Hydrogeology, Department of Geology, Ghent University, \\ 9000 Gent, Belgium; marc.vancamp@ugent.be (M.V.C.); mizan@juniv.edu (M.M.R.S.); \\ kristine.walraevens@ugent.be (K.W.) \\ 2 Department of Geological Sciences, Jahangirnagar University, Savar, Dhaka 1342, Bangladesh; \\ bdh2judgs@yahoo.com \\ 3 Dhaka Water Supply \& Sewerage Authority, Dhaka 1215, Bangladesh; shahina.ruet@gmail.com \\ * Correspondence: mazeda.islam@ugent.be or mazeda@juniv.edu
}

check for

updates

Citation: Islam, M.; Van Camp, M.; Hossain, D.; Sarker, M.M.R.; Khatun, S.; Walraevens, K. Impacts of Large-Scale Groundwater Exploitation Based on Long-Term Evolution of Hydraulic Heads in Dhaka City, Bangladesh. Water 2021, 13, 1357. https://doi.org/10.3390/ w13101357

Academic Editor: Maurizio Polemio

Received: 17 April 2021

Accepted: 8 May 2021

Published: 13 May 2021

Publisher's Note: MDPI stays neutral with regard to jurisdictional claims in published maps and institutional affiliations.

Copyright: (c) 2021 by the authors. Licensee MDPI, Basel, Switzerland. This article is an open access article distributed under the terms and conditions of the Creative Commons Attribution (CC BY) license (https:// creativecommons.org/licenses/by/ $4.0 /)$.

\begin{abstract}
Dhaka city has emerged as the fastest-growing megacity, having more than 20 million inhabitants, with a growth rate of $3.62 \%$. Unplanned and rapid urbanization, coupled with exponential population growth, has significantly altered the groundwater dynamics in Dhaka city. This study concentrates on the evolution of long-term piezometric heads of the Upper Dupi Tila aquifer (UDA) and the Middle Dupi Tila aquifer (MDA) based on long-term hydrographs, piezometric maps and synthetic graphical overviews of piezometric trends. Due to over-exploitation, the piezometric level (PL) has declined deeper than -85 and $-65 \mathrm{~m}$ PWD (Public Works Department reference datum) in UDA and MDA, respectively. The highest rate of decline was observed in the south-central to southeastern parts of the city both in UDA (4.0 m/year) and MDA (5.74 m/year). The results clearly show that the rates of decline in PL vary from 2.25 to $5.74 \mathrm{~m}$ /year in both aquifers of the city, and urban expansion has greatly affected the shape and extent of the depression cone over the past four decades. The magnitudes of the depression cones in both aquifers seem to pose a considerable threat to groundwater resources, indicating that the current exploitation is not sustainable at all.
\end{abstract}

Keywords: groundwater over-exploitation; population growth; city expansion; hydrographs; piezometric maps; depression cone

\section{Introduction}

Groundwater overexploitation due to urban expansion and population growth is a critical issue in Dhaka city [1], as it is in many other developing or developed cities in the world such as in Beijing [2,3], Central India [4], the Indus Basin [5], Northwest India [6], Northern Chile [7], California's Central Valley in the U.S. [8], the U.S. High Plains [9], the Middle East [10], the Hai River plain in China [11] and Belgium [12], among others. A continuous decline in groundwater levels (GWLs) has been observed in many places in the past half-century $[13,14]$ but there is no efficient and adequate approach to groundwater sustainability [13]. Mexico, Melbourne, Jakarta, São Paulo, Central Iran, Chennai and major cities in India have been critically affected by massive groundwater abstraction and have already experienced land subsidence and the drying up of rivers and wetlands [6,15-24].

Dhaka, the capital of Bangladesh, is densely populated and is the largest city in the country. It is the world's 6th most populated city [25]. It started to expand exponentially after the independence of Bangladesh in 1971. This exponential population growth accelerated groundwater abstraction in order to meet the water demand. In $2018,78 \%$ of the supply water came from underground sources and $22 \%$ from treating surface water [26]. 
This large-scale uncontrolled groundwater extraction is being carried out without sustainable management or a proper understanding of the aquifer system. The massive pumping has changed the natural hydrologic system both within the city and far beyond the city limits $[27,28]$.

The lowering of the groundwater level can be triggered by intensive abstraction or the reduction of groundwater recharge [3]. Excessive pumping changes the groundwater flow from horizontal to vertical [29]. The decline of GWLs in Dhaka city has been expedited due to large-scale abstraction $[1,30]$ and unplanned urbanization. Globally, from the 1950s onward, the rate of depletion of the groundwater level has increased markedly but the maximum rates have occurred since 2000 [13,31]; this poses an alarming threat to the sustainability of water supplies [13]. The sustainability of groundwater is very complicated [32] and is related to noticeable socio-economic challenges [33-35]. Sustainable groundwater exploitation considers groundwater as a renewable resource [36,37], but the mean residence time of groundwater ( $<10$ to $>1,000,000$ years) [38] is far longer than that of the other parts of the hydrologic cycle [39]. The main obstacle for long-term groundwater sustainability is the fact that the policy horizons are not persistent with the natural groundwater time scales [32].

The quantification of groundwater lowering and the development of a monitoring network is very important for effective groundwater resource management $[3,40]$. Several researchers $[1,27,28,41-48]$ have investigated the GWLs of Dhaka city, and the leakage and dewatering process have also been considered in order to protect the environment [49-51]. Almost all these previous works have mainly focused on the piezometric level (PL) of the upper part of the semi-confined Dupi Tila aquifer, which is limited to a maximum depth of $100 \mathrm{~m}$. However, most researchers did not consider the sub-division of the aquifer.

In this study, long-term hydrographs and piezometric maps of piezometric levels for UDA (with an average bottom depth of $143 \mathrm{~m}$ ) and MDA (with an average bottom depth of $255 \mathrm{~m}$ ) have been interpreted and discussed. The evolution of the PL of LDA (with an average bottom depth of $420 \mathrm{~m}$ ) is not yet monitored by any organization and therefore the piezometry of LDA could not be assessed due to the unavailability of data. The present investigation is an attempt to study the impact of urbanization and rapid population growth on the groundwater regime in Dhaka city.

\section{Study Area}

\subsection{Location and Extent}

Geographically, Dhaka is located in central Bangladesh, between longitudes $90^{\circ} 19^{\prime} 10.37^{\prime \prime} \mathrm{E}$ and $90^{\circ} 31^{\prime} 1.61^{\prime \prime} \mathrm{E}$ and latitudes $23^{\circ} 40^{\prime} 49.9^{\prime \prime} \mathrm{N}$ and $23^{\circ} 54^{\prime} 46.5^{\prime \prime} \mathrm{N}$. The study area lies in the central part of Bangladesh and covers a total area of 306 square kilometers (Figure 1). Dhaka city has observed major growth in its population over the last three decades due to migration from the countryside and townships [52]. It is surrounded by four major rivers-Buriganga, Turag, Balu and Shitlakhya - and a canal called Tongi khal which periodically suffers from flooding. The Ganges, Jamuna and Meghna river floodplains encompass Dhaka city [53,54]. 


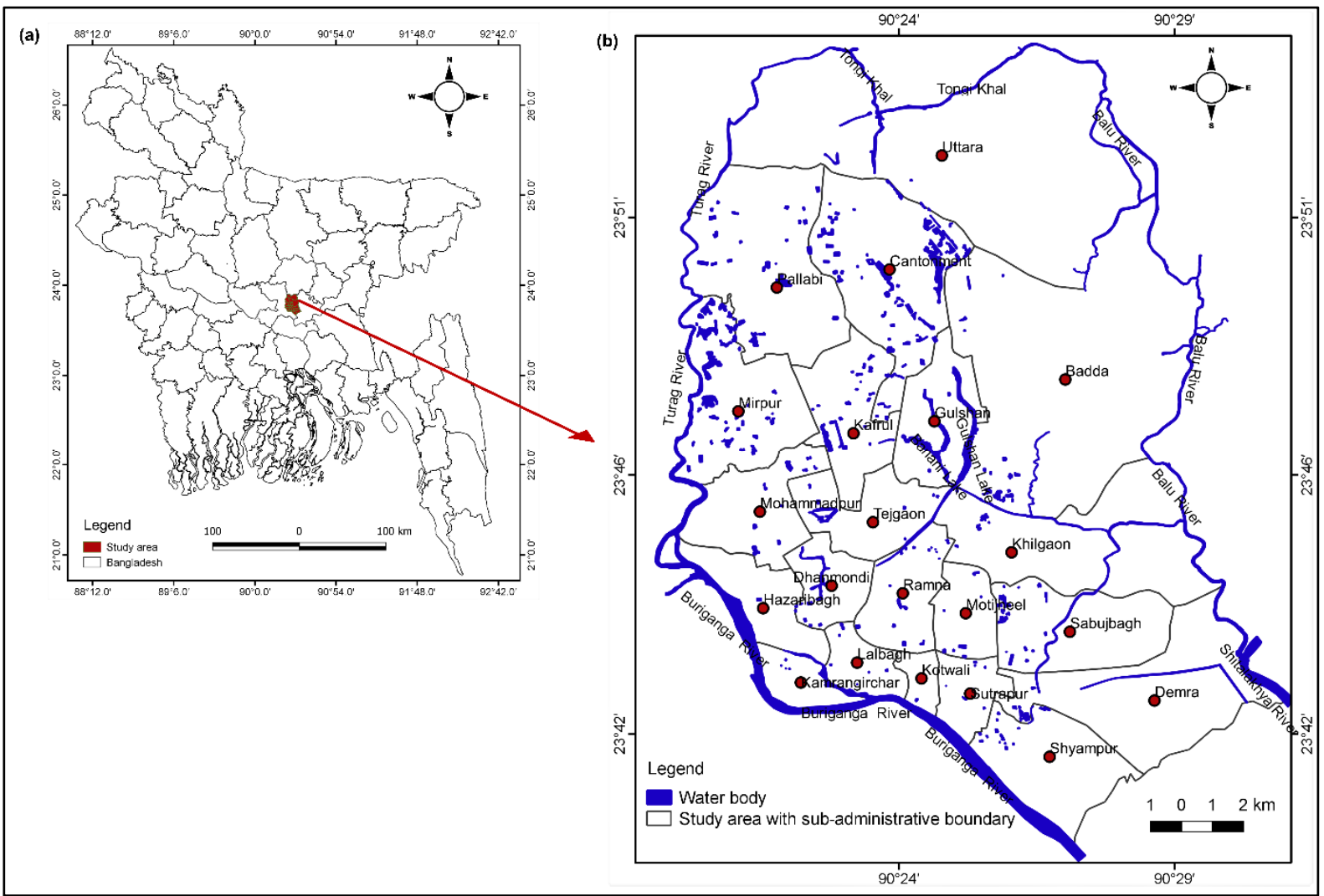

Figure 1. (a) Location of Dhaka city in the central part of Bangladesh. (b) Study area (Dhaka city) map with subadministrative boundary.

\subsection{History of the Expansion of Dhaka City}

The pattern of expansion and urbanization of Dhaka city has mainly been shaped by the landscape and elevation of the land [55]. The historic evolution of Dhaka city generally followed two patterns: old Dhaka or the historic core, and new Dhaka or the northern expansion [56]. The city reached its present status, with its fast-growing population and increasing size, through a series of progressive changes. The history, growth and development of Dhaka can be categorized into six periods: the pre-Mughal period (1205-1610), the Mughal period (1620-1757), the East India Company period (1758-1858), the British colonial period (1858-1947), the Pakistan period (1947-1971) and the Bangladesh period (from 1971 onwards) [45,57] (Figure 2).

In the pre-Mughal period, about 400 years ago, Dhaka was limited to an area of $1.5 \mathrm{~km}^{2}$ around the river Buriganga [45,57]. According to Chowdhury and Faruqui (1989) [58], Dhaka attracted European traders-the Portuguese, the Dutch, the English, the French and the Armenians-because of its commercial importance and they established their trading posts in the 18th century. In the British period, Dhaka expanded to $22 \mathrm{~km}^{2}$ and in the Pakistan period to $50 \mathrm{~km}^{2}$. The city extended and developed to the west and the north during the Mughal and British periods. Dhaka city was established as the capital of East Pakistan in the Pakistan period. This city progressively became the central point of attraction and development towards the north. A large number of people from other districts started migrating to Dhaka from the Pakistan period onward [59].

After the independence of Bangladesh in 1971, the main urban development and rapid expansion started in Dhaka. The development expanded from the old area towards the west and north in the period between 1972 and 1980 [60,61]. From 1980 to 1990, the city expanded up to Mirpur, Airport and further north to the banks of the Turag river. The expansion to the east and northwest was limited due to the presence of lowlands and depressions, and therefore major development occurred along the north-south corridor 
of Dhaka city [55]. Initially, the progress of development was limited to the available highlands. But later on, development also occurred in the low-lying areas. The major land filling areas were mainly in the eastern and south-eastern parts of the city [60].

Until 1990, the main city was restricted between the Balu and Turag rivers in the east and west, respectively, due to the area beyond this limit being low, swampy and floodaffected [62]. In 1996, the Dhaka Metropolitan Development Plan (DMDP) administered by Rajdhani Unnayan Kartripakkha (RAJUK) provided a long-term strategic plan up to 2015 for the development of a greater Dhaka, which includes Dhaka city and its surrounding six municipalities $\left(1528 \mathrm{~km}^{2}\right)$ [63]. In the 1990s and 2000s, the new Dhaka expanded north to its present boundaries. Between 2000 and 2015, the city expanded continuously in all directions and occupied all the vacant spaces $[60,62,64]$. The city did not yet have any definite and well-planned outline for homogenous and cohesive growth; rather, different private organizations occupied and filled up major ditches, swamps and marshes in an unplanned manner $[65,66]$.

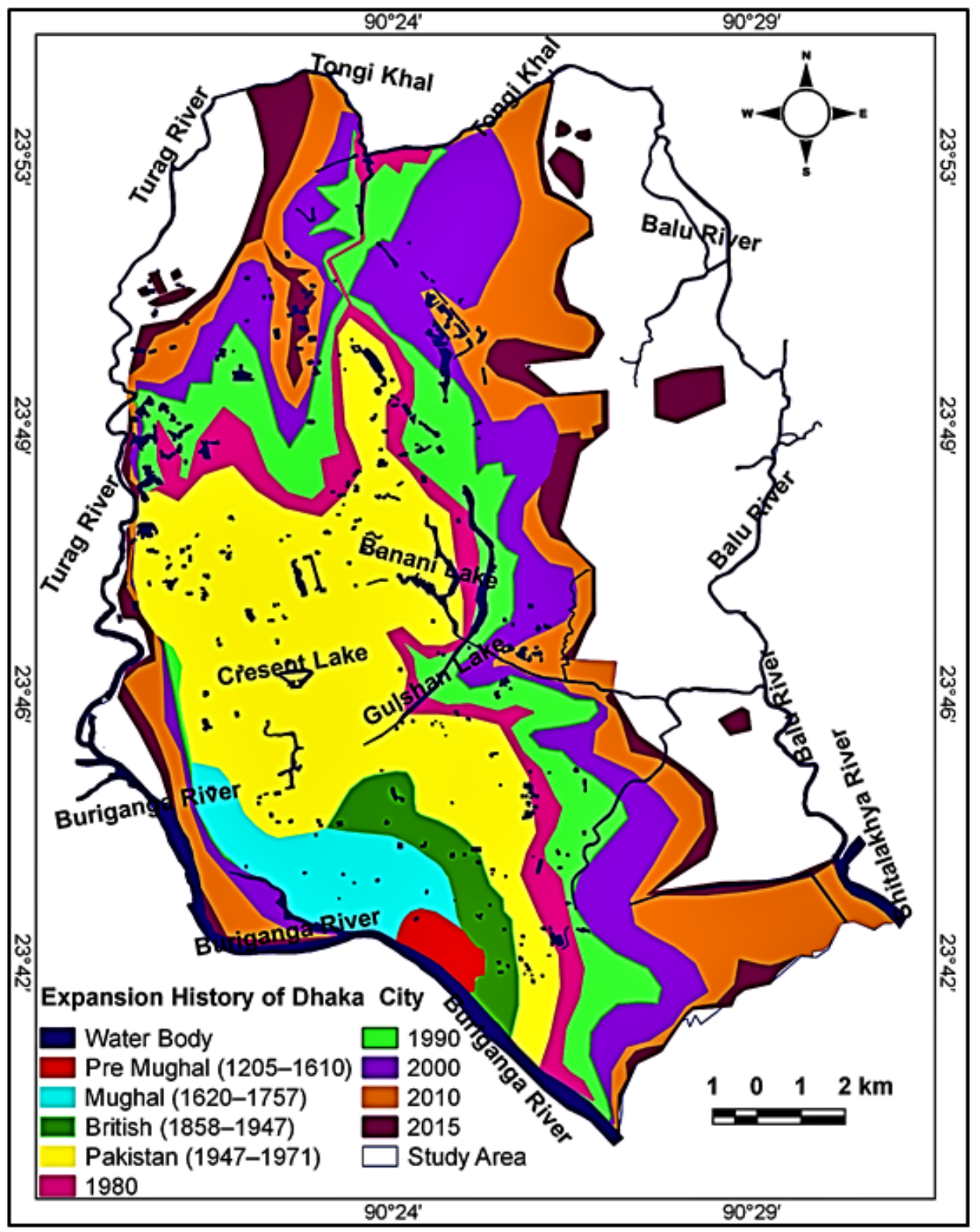

Figure 2. The historical development of Dhaka City at different stages of its growth (modified from $[60,67])$. 


\subsection{Climate}

Dhaka city has a humid tropical monsoon-type climate with an annual average rainfall of $1955 \mathrm{~mm}$. About $80 \%$ of the annual average rainfall occurs between the months of May to October. The average potential evaporation is $836 \mathrm{~mm}$ per annum. The average relative humidity ranges from $55 \%$ to $79 \%$. The maximum monthly average temperature is $30{ }^{\circ} \mathrm{C}$ in June and the minimum monthly average temperature is $19^{\circ} \mathrm{C}$ in January (Figure 3).

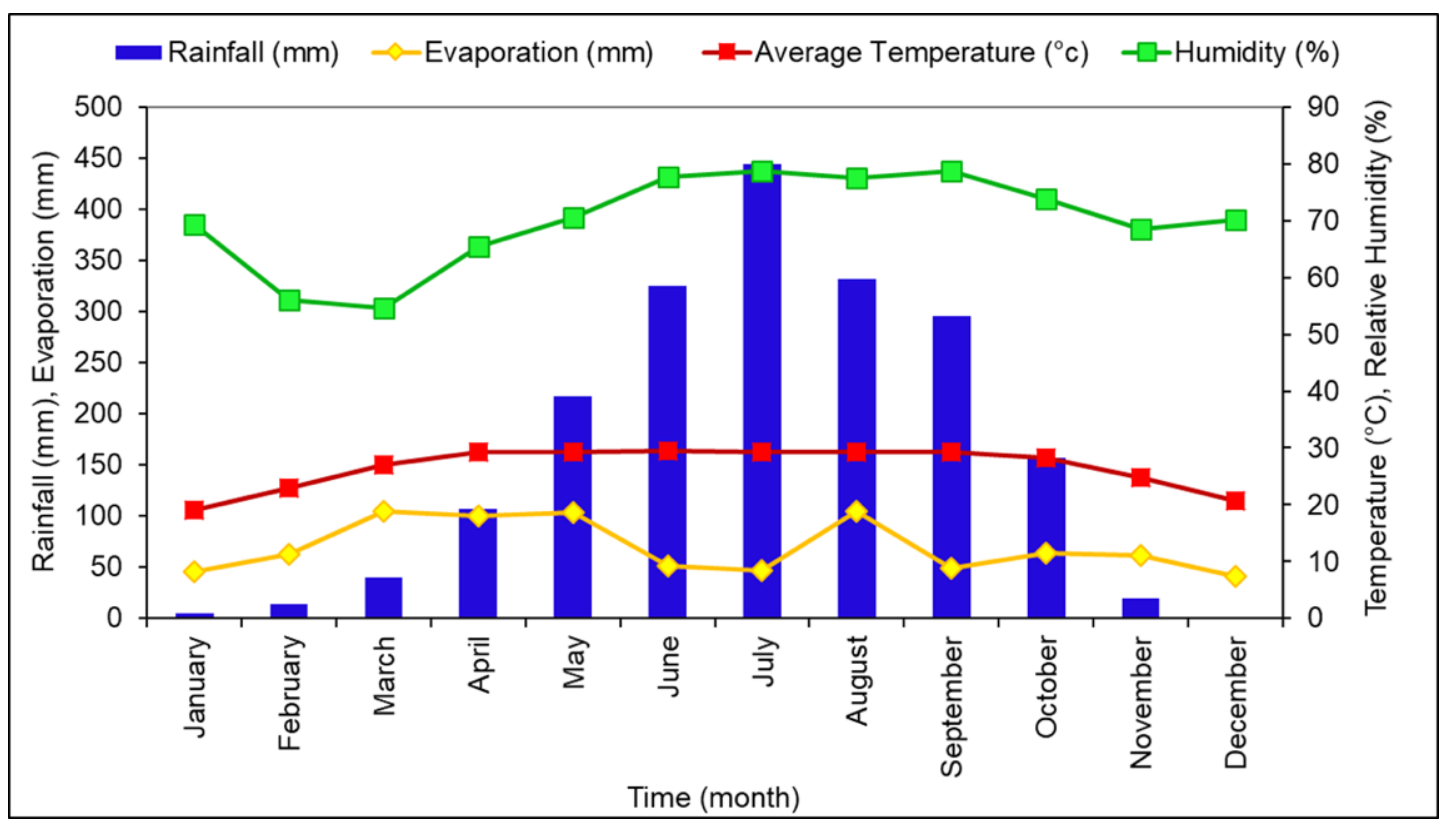

Figure 3. Long term (2005-2016) monthly average rainfall $(\mathrm{mm})$, average temperature $\left({ }^{\circ} \mathrm{C}\right)$, potential evaporation (mm) and relative humidity (\%) in Dhaka city.

\subsection{Geomorphology, Surface Geology and Topography}

Dhaka is situated in the southern extremity of the Madhupur tract, a north-south elongated Pleistocene terrace [54] having an undulating topography, elevated from the Recent floodplain [53]. Fifteen geomorphic units have been noted, but centrally most of the parts are covered by the Madhupur terrace unit (Figure 4a). Most of the north-eastern, middle eastern and northwestern margins remarkably cover swamp or depression units. All low-lying geomorphic units, e.g., alluvial valley, active flood plain, natural levee, point bar, abandoned channel bed, swamp and depression area, have already been filled up due to rapid urban growth.

The surface geology mainly follows the geomorphic expression of the area (Figure 4b) and is classified into four broad categories: Madhupur Clay residuum, Alluvium silt and clay, Alluvium silt, and Marshy peat and clay. From a geological and geomorphological perspective, the city mainly covers two broad geomorphological units. One is high lands, which correspond to Madhupur terrace, and the other is lowlands, which correspond to alluvial deposits, mainly comprising swamp or depression, back swamp, channel bar, flood plain and valley fill units $[68,69]$. The relatively flat topography also perfectly resembles the geomorphic features of the area. The western part is marked by an abrupt change in elevation, whereas relatively gentle slopes are maintained in the eastern part. The surface elevation of gullies, valleys and bars is somewhat higher $(>9 \mathrm{~m})$ in the southwestern and northeastern parts than in the floodplain, depressions and abandoned channels, but the undulating topography was mainly created or developed by the rivers Buriganga, Balu and Turag. The general slope of the land surface is from north to south, more specifically towards the southeast, in which ground surfaces merge with the Recent floodplain of the rivers Buriganga, Balu and Shitalakhay. The elevation differences are remarkably reflected by distinct landforms: a high elevation is observed in the Madhupur terraces 
region, normally ranging from $15 \mathrm{~m}$ to $>20 \mathrm{~m}$ above mean sea level (amsl), and a low elevation $(<5 \mathrm{~m}$ amsl) is observed in the floodplain, depressions and abandoned channels (Figure 5a).

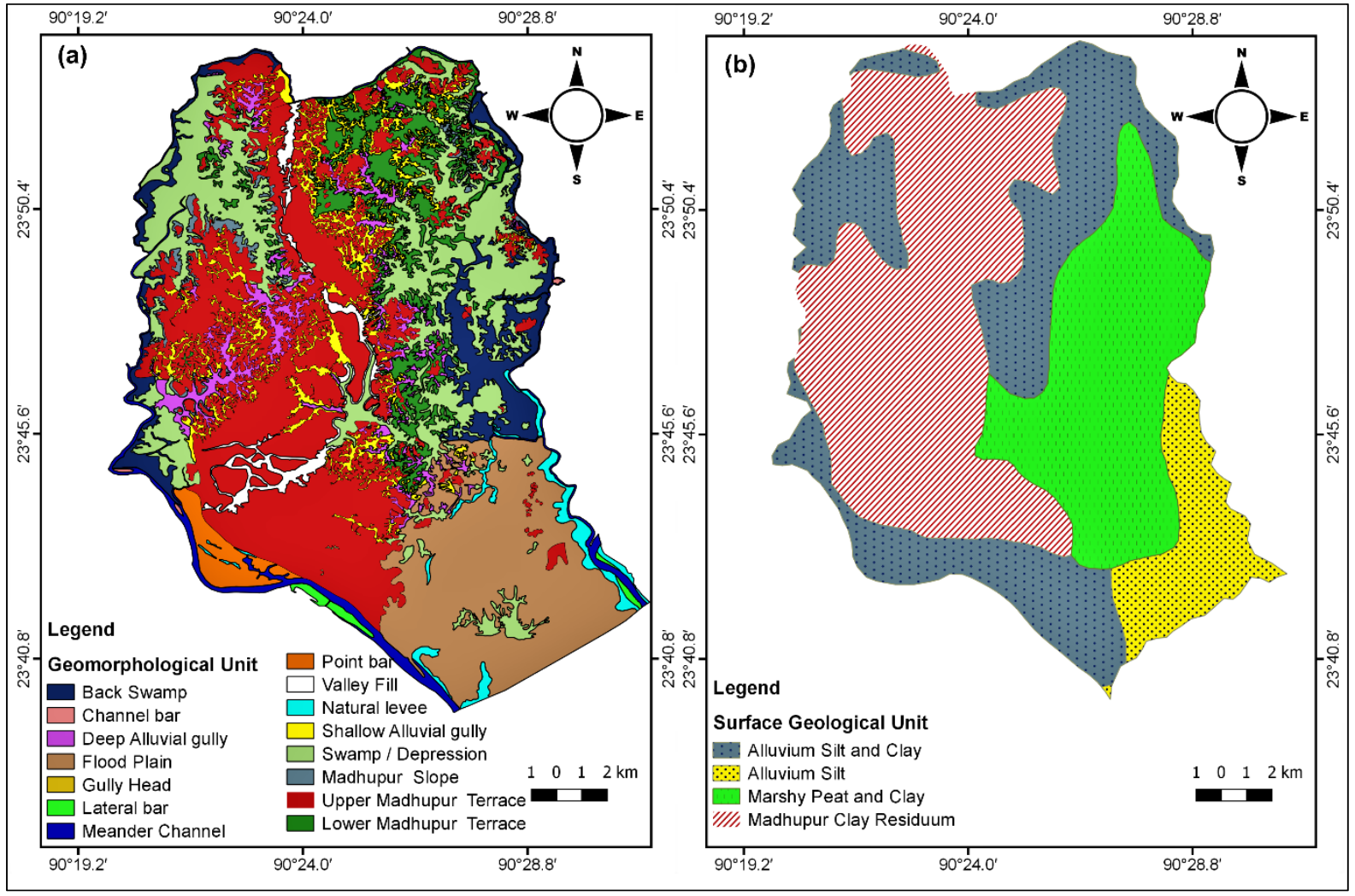

Figure 4. (a) Geomorphological map and (b) Surface geological map of Dhaka city.

\subsection{Geology}

Dhaka city is distinguished by a 400- to 500 -m-thick unconsolidated sequence of fluvio-deltaic sediments which are overlain by Madhupur Clay or floodplain materials, which are 5 to $25 \mathrm{~m}$ thick [1]. This underlying unconsolidated layer acts as the main aquifer and is known to be a part of the Dupi Tila Formation [70]. The Pleistocene alluvial terraces are very weathered, oxidized, more compacted than the Recent floodplains and are represented as paleo-floodplains of the previous Ganges Brahmaputra Meghna (GBM) system [54,71]. The eroded part of the Madhupur Formation and the subsided part of the floodplain and depressed areas are believed to have been filled by the Bashabo Formation. The Holocene Bashabo Formation mainly consists of sand, silt and clay and serves as a localized shallow aquifer on top of the Madhupur Formation, merging with the floodplain deposits in the southeast part of Dhaka city [53,72]. The Madhupur Tract around Dhaka city is characterized by a large number of faults $[70,73]$ that significantly control the local rivers and possibly affect the aquifer and river interaction. The rivers and stream systems flowing along this fault system possibly cut Dupi Tila sands [1,70]. A series of six secondary echelon faults occur in the western margin of the Madhupur Tract. A coupled force is acting that increases deep slip as well as strike-slip movement along the main Madhupur Fault. For this reason, the uplifted Madhupur Tract is moving towards the north, whereas the downthrown Jamuna floodplain is sliding towards the south [74]. It is expected that the Girujan Clay Formation is underlying the Dupi Tila Formation in Dhaka city. The Girujan Clay Formation was neither exposed nor penetrated by drilling but is assumed based on its extensive occurrences in a different place in Bangladesh [41]. The stratigraphic units of the study area, from oldest to youngest, are the Girujan Clay (Pliocene), Dupi Tila 
Sands (Plio-Pleistocene), Madhupur Clay (Pleistocene), Bashabo Formations (Holocene) and Alluvium (Recent).

\subsection{Hydrostratigraphy and Aquifer Delineation}

The study area has been geologically and hydrogeologically investigated by many researchers $[1,41-43,45,70,72,75-77]$ but the geology, stratigraphy and hydrostratigraphy are not well defined because of the limited depth investigated. Almost all the investigations have been limited to the upper part of the Dupi Tila Formation $(<170 \mathrm{~m})$. In this study, an attempt has been made to delineate the more detailed hydrostratigraphy and aquifer geometry at a greater depth (up to $463 \mathrm{~m}$ ). The thickness of the hydrostratigraphic units varies laterally and vertically because of surface topography and changes in the depositional conditions [71], that is, the heterogeneity of the layers [71,78]. A hydrostratigraphic reconstruction was performed based on lithologs from the Bangladesh Water Development Board (BWDB), the Department of Public Health Engineering (DPHE) and the Dhaka Water Supply and Sewerage Authority (DWASA). Golden Software's Strater ${ }^{\circledR}$ was used for the interpretation of the lithology and for generating cross-sections. First, the location of the borehole logs was mapped using Strater ${ }^{\circledR} 5$. Suitable lines were chosen for the lithological cross sections. The borehole logs were then plotted along the cross-section line. The aquifers and aquitards were delineated manually, based on lithology, using the drawing option in Strater ${ }^{\circledR} 5$. Similarly, the PL in each borehole log along the cross-section was inserted and then connected manually to show the PL. The generalized hydrostratigraphy was established based on lithology and, chronologically, from the surface up to the explored depth $(463 \mathrm{~m})$, the units are: localized shallow aquifer, aquitard, Upper Dupi Tila Aquifer (UDA), aquitard, Middle Dupi Tila Aquifer (MDA), aquitard, Lower Dupi Tila Aquifer (LDA) and aquitard.

The top aquitard unit is composed of silty clay, sandy silt and clay. The depth to base varies from 5 to $64 \mathrm{~m}$ and the average thickness is $30 \mathrm{~m}$ (Figure $5 \mathrm{~b}-\mathrm{d}$ ). The UDA is overlain by this top aquitard and underlain by another aquitard. This aquifer is semi-confined. The UDA consists of unconsolidated sands of varying size: very fine sand to fine sand, fine sand to medium sand, and medium sand to coarse sand occasionally with gravel (Figure 5b-d). The depth to base of UDA is generally 90 to $170 \mathrm{~m}$ and, on average, the bottom depth is $143 \mathrm{~m}$. The average thickness is $98 \mathrm{~m}$. In most parts of the city, the transmissivity values of UDA range from 400 to $500 \mathrm{~m}^{2} / \mathrm{d}$ and the storativity values range from $1.5 \times 10^{-6}$ to $9.5 \times 10^{-5}$ but are mainly around $2 \times 10^{-5}$ [79]. There are laterally discontinuous clay or silty clay layers in the Dupi Tila Formation, which are also regarded as local aquitards within UDA, MDA and LDA. The second aquitard is present between UDA and MDA, and is composed of sandy silt, silty clay and clay, with an average thickness of $32 \mathrm{~m}$. MDA is mainly composed of fine-to-medium sand and medium-to-coarse sand, occasionally with gravel. The depth to its base ranges from 190 to $295 \mathrm{~m}$, with an average thickness of $86 \mathrm{~m}$. In MDA, the average transmissivity, storage coefficient and hydraulic conductivity in Mirpur are reported to be $1756.14 \mathrm{~m}^{2} / \mathrm{d}, 0.0029 \mathrm{~m} / \mathrm{d}$ and $22.16 \mathrm{~m} / \mathrm{d}$, respectively, whereas in Tejgaon, they are $1854.94 \mathrm{~m}^{2} / \mathrm{d}, 0.0019 \mathrm{~m} / \mathrm{d}$ and $32.03 \mathrm{~m} / \mathrm{d}$, respectively [80]. A very thick aquitard underlies MDA and the depth to its base ranges from 378 to $384 \mathrm{~m}$ (in the few boreholes that crossed this layer). The LDA is predominantly composed of fine-to-medium sand and medium-to-coarse sand. The depth to its base varies from 420 to $426 \mathrm{~m}$ and the average thickness is $40 \mathrm{~m}$ (in the few available boreholes). Very few lithologs are available for the purpose of illustrating the LDA (Figure 5d). 


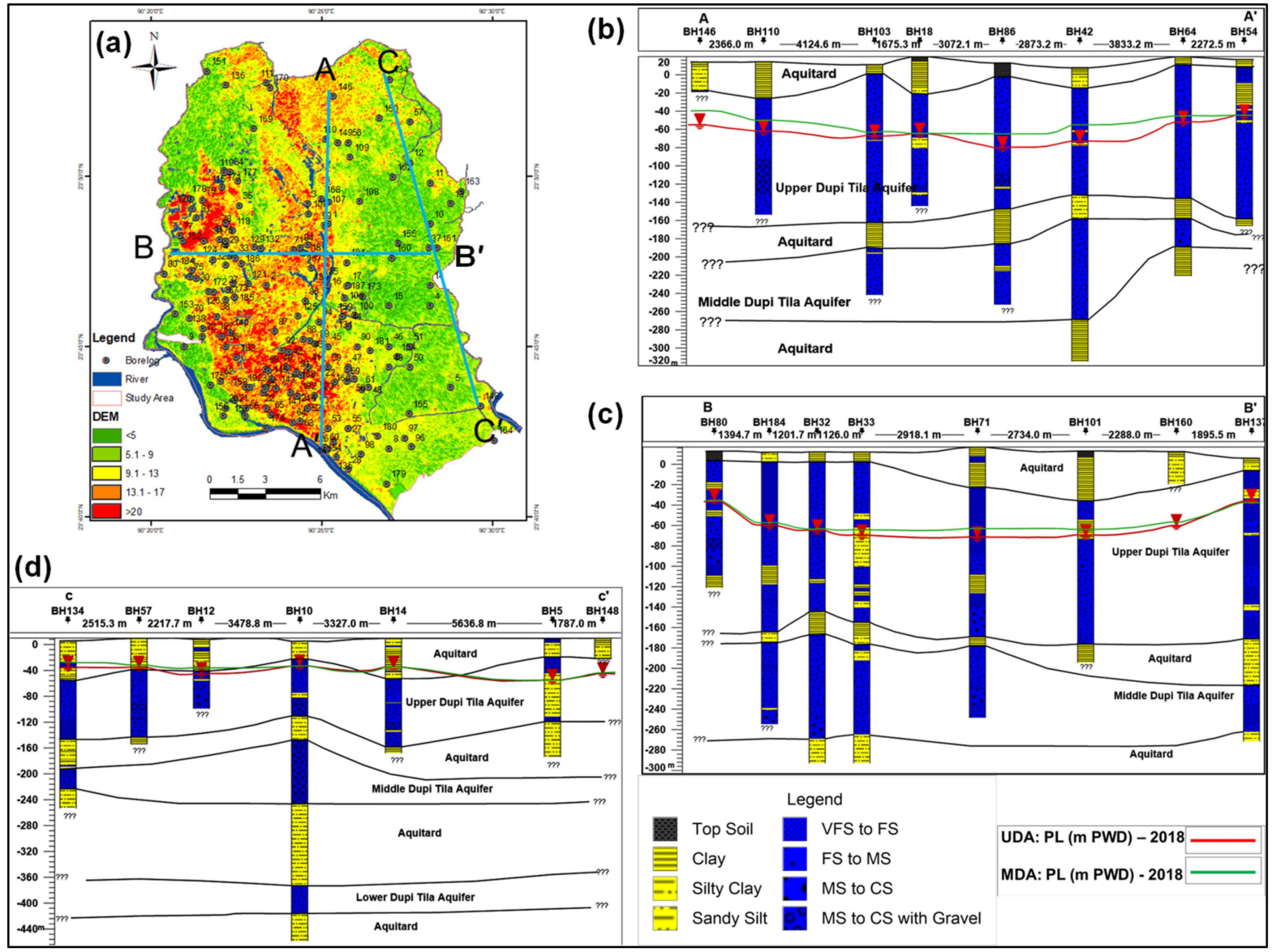

Figure 5. (a) Digital elevation model (DEM) map [81] showing the location of 188 boreholes with lithologs, along with the orientation of the cross-section lines in the study area. (b) N-S (AA') trending hydrostratigraphic cross section with PL_2018. (c) W-E $\left(\mathrm{BB}^{\prime}\right)$ trending hydrostratigraphic cross section with PL_2018. (d) NE-SE (CC') trending hydrostratigraphic cross section with PL_2018.

\section{Abstraction Scenario for an Expanding Dhaka City}

The groundwater exploitation scenario is directly linked with the population of the area, urbanization and city expansion. In Dhaka city, groundwater extraction has been reported since the 16th century: Guru Nanak sunk a dug well due to the scarcity of water [82]. In the 1980s, dug wells were also used as a source of drinking water, and still today some dug wells are found in the alluvial cover on top of the Madhupur Clay. In 1874, Nabab Khaja Abdul Ghani first established a water treatment plant in the Chadnighat area near the bank of the river Buriganga to supply water to Dhaka city [45]. The DPHE introduced groundwater development for a public supply and drilled the first borehole in Dhaka in 1941 [45,57]. Then the use of groundwater increased gradually over time as a source of water production [45]. Since 1963, DWASA has been continuously expanding its coverage area with updated services $[45,57]$. Figure 6 shows the development of production wells, along with water demand and production and population with time. The independence of Bangladesh in 1971 prompted the advance and development of the groundwater supply [30]. The city had a population of less than two million and groundwater abstraction was less than $50 \times 10^{6} \mathrm{~m}^{3}$ /year during that time, and only 47 DWASA deep tube wells (DTWs) were operating [26]. From 1970 to 1985, almost all the DTWs were installed in UDA in the vicinity of the rivers Buriganga and Turag, whereas later on, well construction spread to the center and the northern part of the city. In 2000, the population increased to almost 10 million. DWASA installed a total of 308 DTWs with $413 \times 10^{6} \mathrm{~m}^{3}$ /year production capacity, but demand was $548 \times 10^{6} \mathrm{~m}^{3} /$ year. In addition, more than 900 private deep wells (with a minimum of $0.057 \mathrm{~m}^{3} / \mathrm{s}$ discharge) were also 
operating in the UDA [46]. Since 2004, DWASA has drilled wells to larger depths ( $>170 \mathrm{~m}$ ) in MDA and LDA [80] because of the huge drop in the PL of UDA. In 2013, the supply capacity was raised to $883 \times 10^{6} \mathrm{~m}^{3} /$ year through the use of 644 DTWs and four water treatment plants [26]. In 2018, the population increased to 20 million. To meet the water demand, both the production capacity $\left(931 \times 10^{6} \mathrm{~m}^{3} /\right.$ year $)$ and the number of DTWs (887) were increased [26].

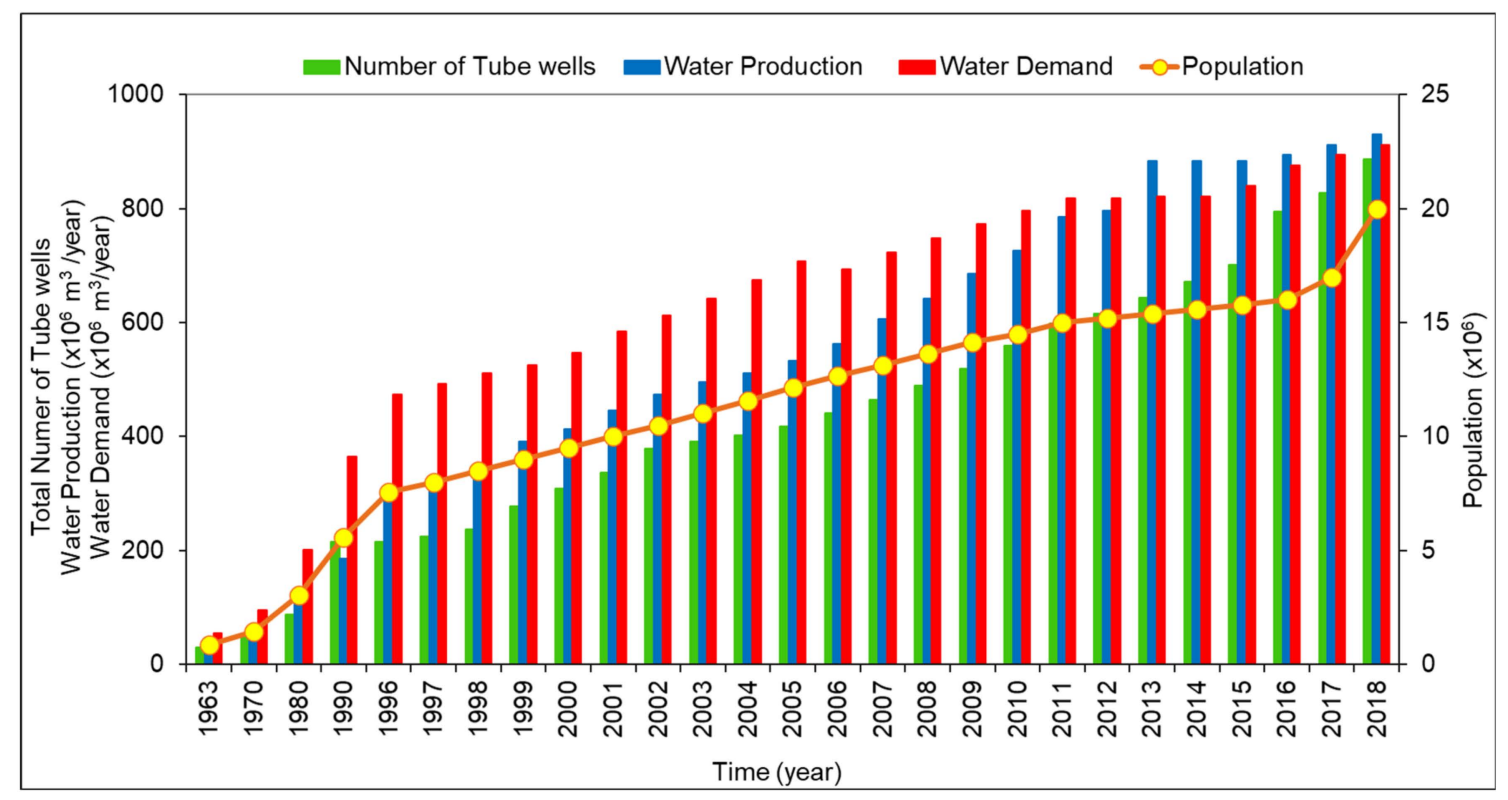

Figure 6. The number of DTWs, water demand and production, and population data.

\section{Methodology: Groundwater Level and Piezometric Data Collection}

Water table data and PL data were collected from BWDB and DWASA in order to prepare long-term hydrographs and piezometric maps of UDA and MDA. DWASA assigned the Institute of Water Modelling (IWM) to establish twin monitoring wells in order to observe the PL of both UDA and MDA [83]. DWASA installed 10 twin monitoring wells in 2005, but data recording was not continuous, and they installed four more twin wells in 2016 (Figure 6). Twin wells are paired wells for monitoring PL in the same area but at different depths, that is, one well in UDA ( $<170 \mathrm{~m}$ depth) and another in MDA ( $>200$ to $<290 \mathrm{~m}$ ).

The water table and PL data were collected from 13 observation wells for the period of 1969 to 2018 from BWDB. Measurements were carried out using manual groundwater measuring devices for 11 observation wells and automatic recording devices for two observation wells (Banani and Lalbagh). The starting dates of measurements by all the piezometers and their depths were not the same. Initially, most of these observation wells were dug wells measuring the water table; then these were subsequently replaced by piezometers. The weekly data from dug wells reflect the water table of that particular area. In some cases, new observation wells were installed in the same or different locations at greater depth, to replace the older wells. In the case of DWASA production wells, the static water level of production wells during well construction was collected. No data were taken from private wells. The PL elevation is calculated with respect to the Public Works Department (PWD) reference datum. The PWD datum is $0.46 \mathrm{~m}$ below the MSL datum [84].

In order to understand the trend of the depression cone in Dhaka city, piezometric maps of UDA and MDA were constructed based on data from observation wells, twin wells and DWASA production wells (Figure 7). To construct piezometric maps, weekly PL data were converted to yearly averages for each observation well from 1980 to 2018 . The piezometric maps for UDA were generated for every 10 years for the period from 1980 to 2010, and for the years 2015 and 2018. Piezometric maps for MDA were also generated for 
the years 2005, 2010, 2015, 2016, 2017 and 2018. DWASA has drilled in MDA since 2004 due to the vast decline of the PL in UDA; for this reason, piezometric maps for this aquifer were prepared starting from the year 2005. The PL data were analyzed using Microsoft Excel. The base map for constructing piezometric maps was prepared using QGIS and the manually prepared PL elevation contours were digitized using QGIS.

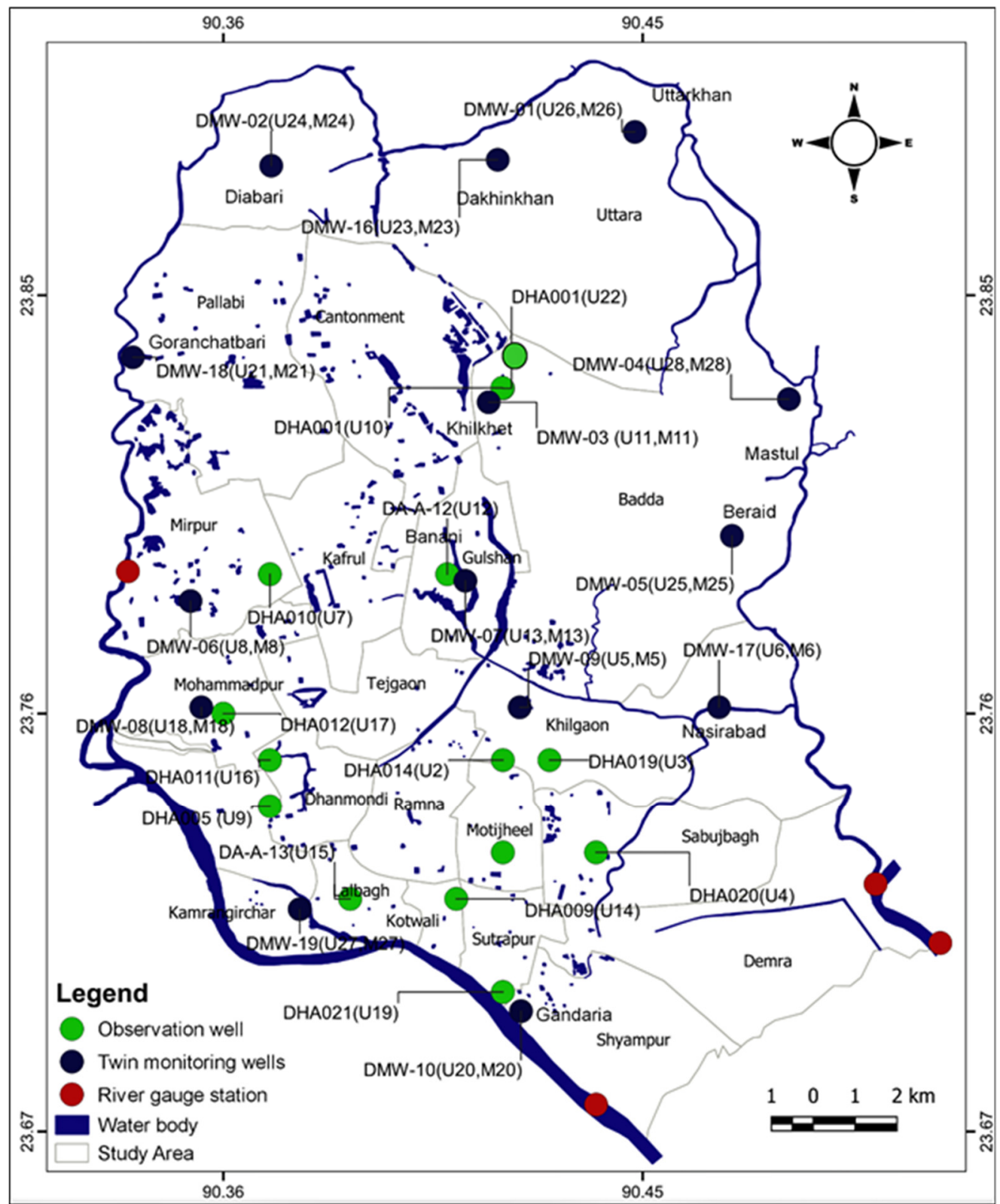

Figure 7. Location map of observation wells, twin monitoring wells and river gauge stations.

\section{Results}

\subsection{Long-Term Hydrographs: Analysis of PL Fluctuation}

The old part of the city was developed in the vicinity of the Buriganga and Turag rivers and, therefore, most of the observation wells are situated in the south-central and western parts of the city. However, twin wells are situated sparsely throughout the city and show the changes of PL in peripheral and central parts of the city. In Dhaka city, most of the observation wells show a continuously declining trend (Figure 8). 
(a) Well ID: DHA014_GT2654014_Motijheel (U2)

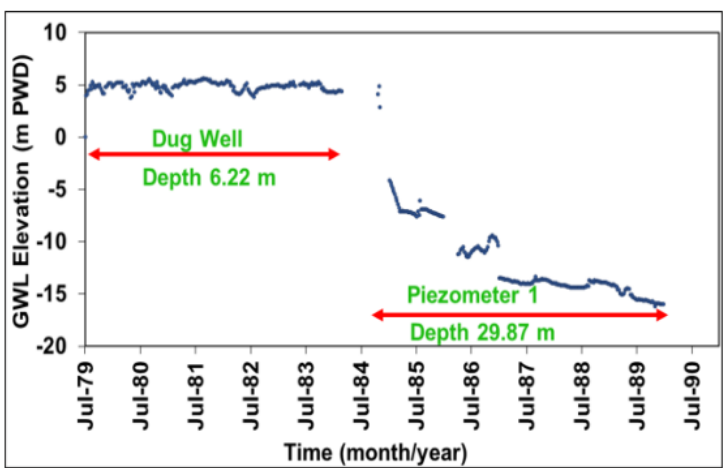

(b) Well ID: DHA020_GT2668020_Sabujbagh (U4)

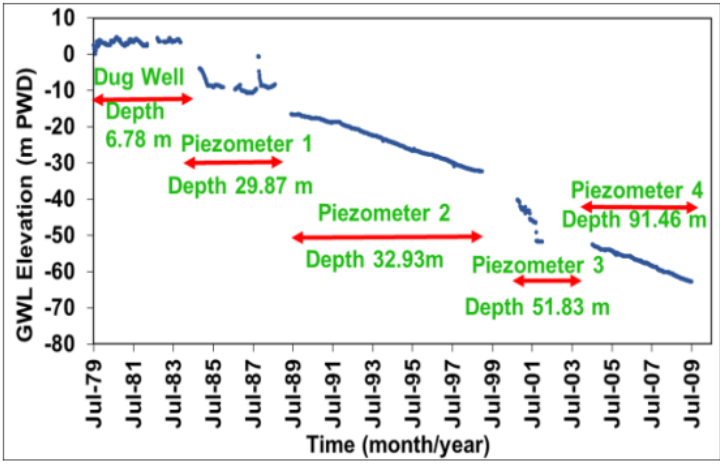

(c) Well ID: DHA010_GT2648010_Mirpur (U7)

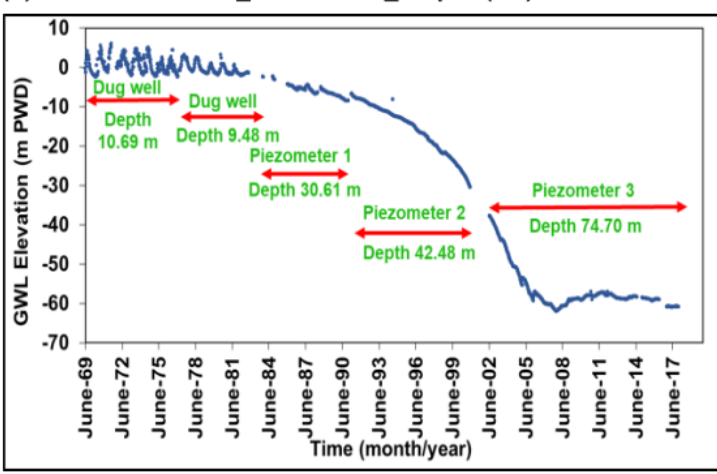

(e) Well ID: DAA012_GT2626900_Banani (U12)

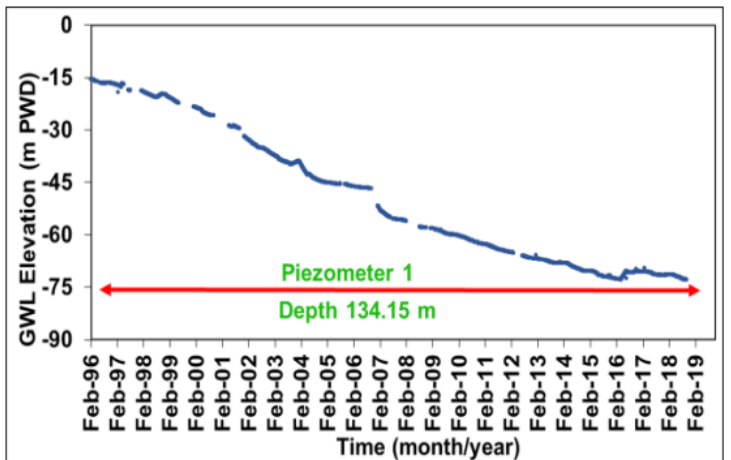

(f) Well ID: DAA013_GT2642900_Lalbagh (U15)

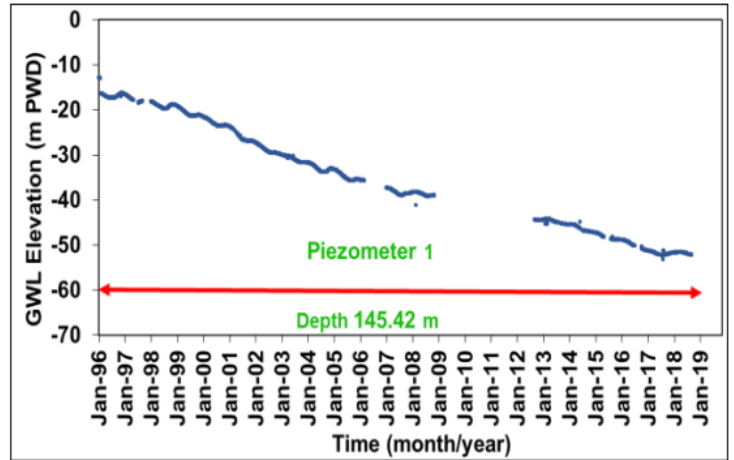

(g) Well ID: DHA011_GT2650011_Mohammadpur (U16)

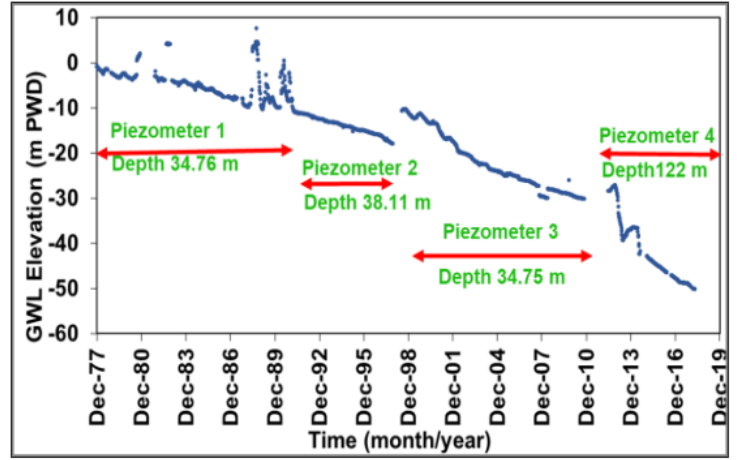

(d) Well ID: DHA001_GT260801_Cantonment_Dhakinkhan (U10_U22) (h) Well ID: DHA021_GT2688021_Sutrapur (U19)
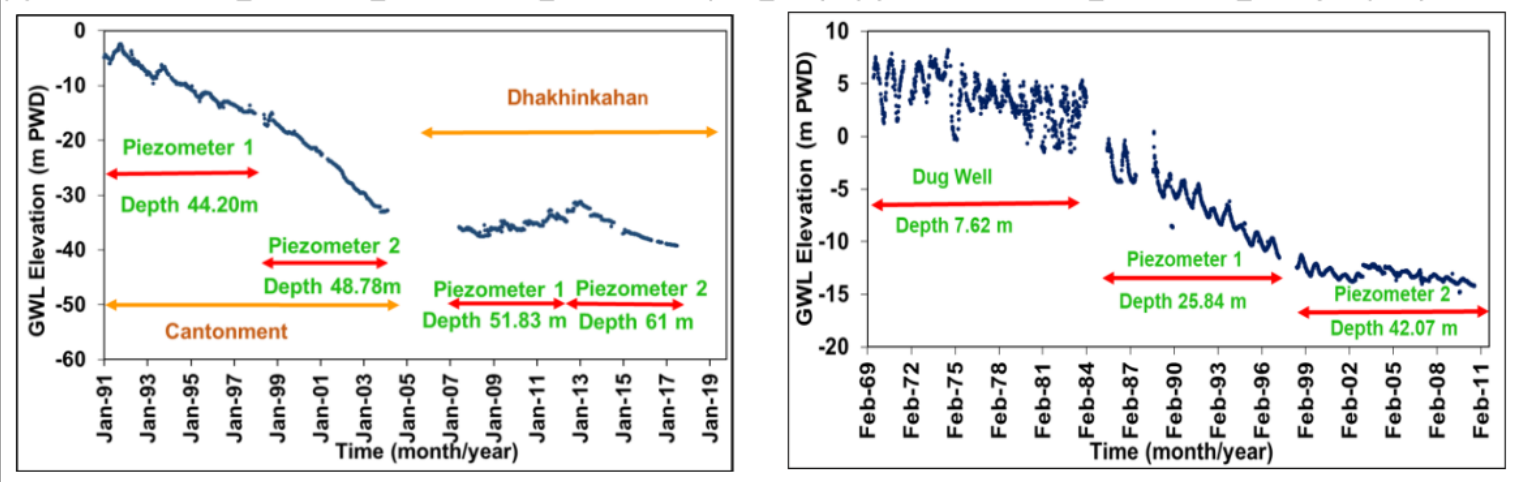

Figure 8. Long-term hydrographs of observation wells in Dhaka city. Note: GWL indicates a dug well and PL indicates a piezometric well in UDA. (a) Well ID: DHA014_GT2654014_Motijheel (U2), (b) Well ID: DHA020_GT2668020_Sabujbagh (U4), (c) Well ID: DHA010_GT2648010_Mirpur (U7), (d) Well ID: DHA001_GT260801_Cantonment_Dhakinkhan (U10_U22), (e) Well ID: DAA012_GT2626900_Banani (U12), (f) Well ID: DAA013_GT2642900_Lalbagh (U15), (g) Well ID: DHA011_GT2650011_Mohammadpur (U16), (h) Well ID: DHA021_GT2688021_Sutrapur (U19). 


\subsubsection{Motijheel (South-Central Part of Dhaka City)}

The Motijheel area became earmarked as the center of regional administration and business activities before 1971 [62,64]. The water table data (dug well, $6.22 \mathrm{~m}$ deep) in Motijheel showed seasonal cyclicity with no declining trend from 1979 to 1984. In 1985, the dug well was replaced by a drilled piezometer. Since then, this well showed a continuously decreasing trend; in the first two years (1985 to 1987) PL declined exponentially with an average of $4.8 \mathrm{~m}$ per year drawdown, and from 1987 to 1989, the lowering trend was linear (Figure 8a). In 1989, the observed PL was $-16.03 \mathrm{~m}$ PWD. Groundwater was exploited at this depth before the construction of the piezometer. After 1985, most of the dug wells were replaced by tubewells, and production wells were also drilled. Water was supplied through pipelines from this part of the city. Thus, the first two years show an exponential decline near the pumping area. After 1987, the well construction was extended to the center and northern parts of the city. The rate of pumping after 1987 in the area of Motijheel decreased gradually and, at the same time, abstraction was disseminated over a larger part of the city, followed by the PL decline becoming linear in this part of the city.

\subsubsection{Sabujbagh (Southeast Part of Dhaka City)}

Motijheel and Sabujbagh are crowded and have been populated since $1950[62,64]$. The first huge lowering of PL was observed in this area, and in 2018, the lowest PL ( $-89 \mathrm{~m}$ PWD) was also noticed here in the UDA. The water table exhibited seasonal cyclicity from 1978 to 1983 (Figure 8b). The dug wells were converted to observation wells into UDA in 1984 but PL data recording was not continuous due to the well being replaced several times due to well failure because of the decline in PL, causing the well to become dry. From 1984 to 1998, the PL showed a linear decline, with a $1.43 \mathrm{~m}$ drawdown per year. The lowering of PL was very sharp in 2000 to 2001drawdown was $11.23 \mathrm{~m}$ and the PL was $-51.78 \mathrm{~m}$ PWD. A significant decline was evident for the period of 2005 to 2009, with PL at -54.54 and $-62.8 \mathrm{~m}$ PWD, respectively. The population increased rapidly during this time (2005-2010). DWASA had a total of 402 DTWs in 2004, whereas in 2010, there were 560. A large number of the DTWs were installed in this part of the city and, therefore, a vast decline was observed here.

\subsubsection{Mirpur (Central West Part of Dhaka City)}

After 1995, the depression extended gradually from the southcentral part to the northwestern part of the city because of population growth and city expansion. The PL declining trend increased with the exponential growth of the population. In 2001, the Mirpur area was more densely populated compared to the Motijheel area [85]. The water table data for the period from 1969 to 1984 showed seasonal fluctuation, with no falling trend. The PL in UDA declined linearly from 1985 to 1995 in the Mirpur area. In 1995, the PL was observed to be $-14.3 \mathrm{~m}$ PWD. After 1995, the PL declined very sharply up to the year 2000 at rate of $3.3 \mathrm{~m}$ /year. Again, PL showed a highly exponential decrease from 2002 to 2005 with an average drawdown rate of $6.9 \mathrm{~m}$ /year and remained relatively steady from 2006 to 2018 (Figure 8c). In 2005, the PL was noted to be $-58.60 \mathrm{~m}$ PWD. After 2005, the PL elevation showed a relatively slower decreasing trend, which directly indicated a lower abstraction rate from the UDA.

\subsubsection{Cantonment and Dhakinkhan (Central North of Dhaka City)}

DHA001 represents the Cantonment area from 1991 to 2004, which was then moved to the Dhakinkhan area in 2007 (Figure 8d). The PL showed a continuous falling trend from 1991 to 2004. The trend was linear from 1991 to 1996 and very steep from 1996 to 2004 and, in 2004, the PL was $-32.86 \mathrm{~m}$ PWD in the Cantonment area. The PL was rising from 2007 to 2013, followed by a linear PL decline. In 2017, the PL elevation was $-39.12 \mathrm{~m}$ PWD. The observation well was shifted to a new location that was less populated than the previous one and where the water abstraction was less. Thus, the shifting of the observation well is 
responsible for the apparent rise in PL at that time. When the city expanded to that area, a PL decline was again observed.

\subsubsection{Banani (Central Part of Dhaka City)}

The observation well DAA012 in Banani showed a continuously declining trend from 1996 to 2018 (Figure 8e). From 1996 to 2004, the PL declined exponentially. The average rate of PL declined by $4.0 \mathrm{~m} /$ year in that period. Again, the strongest decline was observed from 2006 to 2012, followed by gentle decline. Afterwards, the decline was less steep. A linear declining trend with a drawdown rate of $2 \mathrm{~m} /$ year was observed from 2012 to 2016. In 2018, the PL was $-72.95 \mathrm{~m}$ PWD in the Banani area. Though a large lake is situated in this area, it has little influence on the PL declining trends for UDA and MDA. The lake is interacting with the water table aquifer.

\subsubsection{Lalbagh (Southwestern Part of Dhaka City)}

The hydrograph of well DAA013 indicated a continuous declining trend in the PL from 1996 to 2018 (Figure 8f). The falling trend was exponential for the period from 1996 to 2002, followed by linear decline until 2018. From 2012 to 2018, the rate of decline was $1.3 \mathrm{~m}$ /year and the PL elevation was -52.18 m PWD in 2018.

\subsubsection{Mohammadpur (Southwestern Part of Dhaka City)}

The observation well DHA011 showed a linear lowering trend from 1977 to 1997. In 1977, the PL was - $1.43 \mathrm{~m}$ PWD and, after 20 years, the level was $-17.97 \mathrm{~m}$ PWD; that is, the rate of drawdown was $0.97 \mathrm{~m} /$ year, which is low compared to other parts of the city. The PL showed a sharply falling trend from 1998 to 2003, followed by a gentle linear decline from 2003 to 2010. Afterwards, the PL again followed a strong lowering trend from 2012 to 2018, with a drawdown rate of $3.7 \mathrm{~m}$ /year; in 2018, the PL was $-50.3 \mathrm{~m}$ PWD (Figure 8g).

\subsubsection{Sutrapur (South of Dhaka City)}

The observation well DHA021 is located in the southwestern part, near the Buriganga river in Dhaka city. The water table displayed significant seasonal fluctuation from 1969 to 1984. The PL declined linearly from 1985 to 2010, with much smaller drawdown compared to other parts of the city. The PL was $-14.18 \mathrm{~m}$ PWD in 2010 (Figure 8h).

\subsection{Twin Hydrographs: Analysis and Comparison of PL in UDA and MDA}

The twin wells' hydrographs provide an understanding of the interaction of both aquifers at the same time and in the same place. The evolution of the PL values of the twin wells in UDA corresponds in most of the cases with the observation wells' (UDA) data. The twin wells' PL data show that the lowest PL values, at -89.16 and $-62.51 \mathrm{~m}$ PWD in UDA and MDA, respectively, were observed in Khilgaon in the southeast in 2018, with the rate of drawdown being 4.0 and $5.4 \mathrm{~m} /$ year in the UDA and MDA, respectively (Figure 9a). Another twin well in Nasirabad (south east) is situated in Khilgaon (but far from the central part), and this showed a relatively low rate of drawdown (lower than in the central part) (Figure 9b). In 2018, the PL was -52.14 and $-52.25 \mathrm{~m}$ PWD in UDA and MDA, respectively. Both the wells in the central west, in Mirpur, declined distinctly from 2005 to 2019, with the rate of drawdown in MDA (4.6 m/year) being higher than that in UDA (2.85 m/year) (Figure 9c). Because of their different locations, the PL elevation observed in the Mirpur twin wells was not similar to the results of the Mirpur observation well for the period between 2005 and 2006; but later, the twin wells' PLs were similar to that of the observation well. The depression extended to almost the whole of Mirpur (central west) after 2005. The Banani (central) twin wells also indicated a very sharp declining trend from 2005 in both aquifers (Figure 9d). From 2000 onwards, Banani became an expensive diplomatic area in Dhaka city. Thus, the water demand in this area has been very high since then, and a sharp decline has been observed in this area in both aquifers. 
(a) Well ID: DMW-009_Khilgaon (U5_M5)

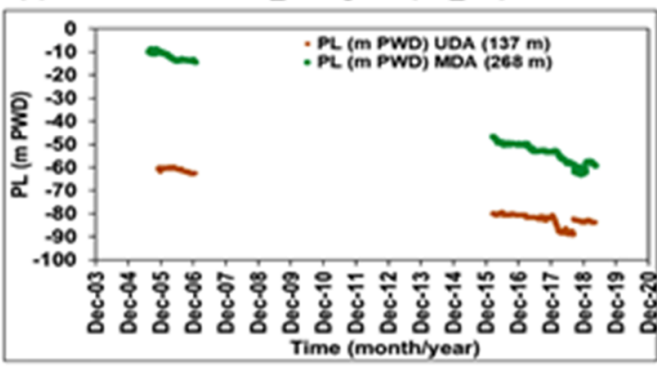

(b) Well ID: DMW-017_Khilgaon ( Nasirabad) (U6_M6)

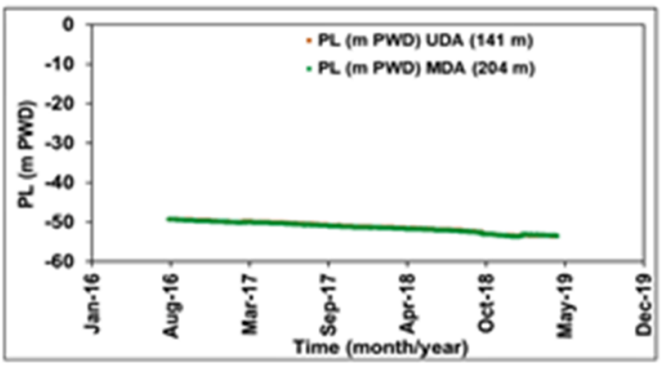

(c) Well ID: DMW-006_Mirpur ((U8_M8)

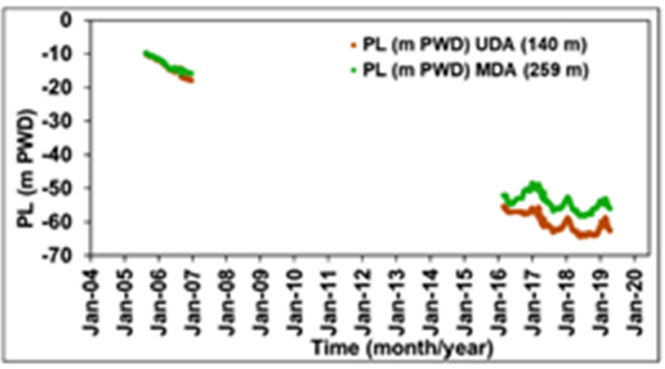

(d) Well ID: DMW-007_Banani (U13_M13)

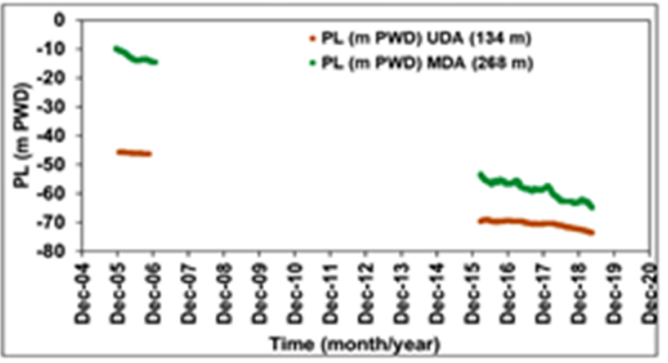

(e) Well ID: DMW-010_Gandaria (U20_M20)

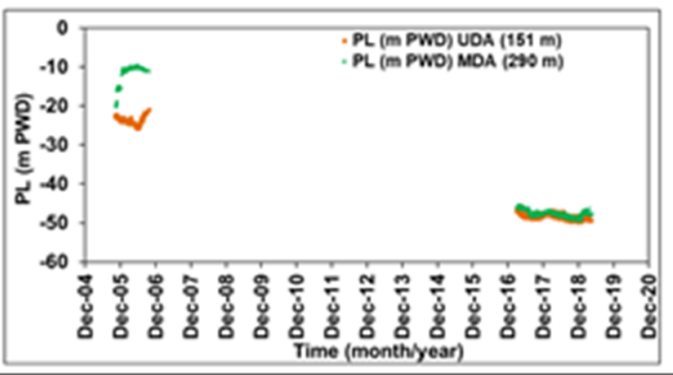

(f) Well ID: DMW-018_Goranchatbari (U21_M21)

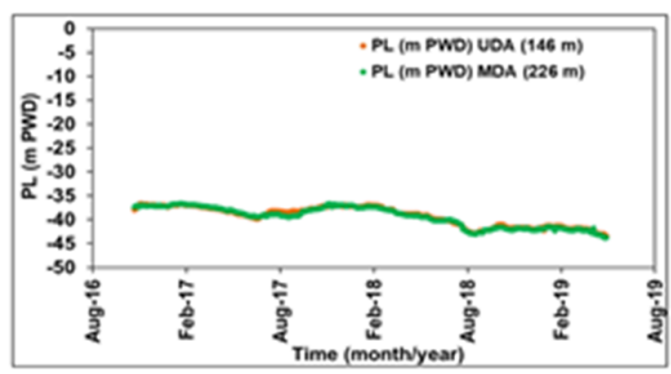

(g) Well ID: DMW-005_Beraid (U25_M25)

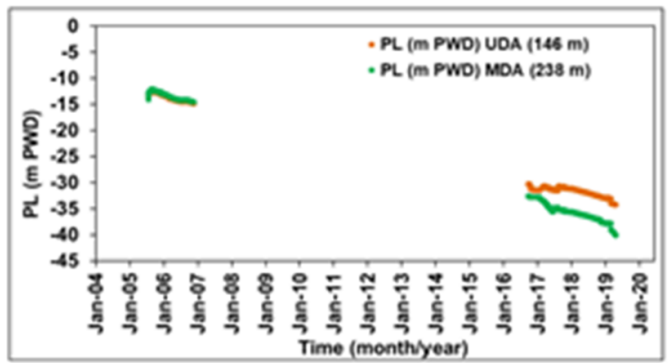

(h) Well ID: DMW-001_Uttarkhan(U26_M26)

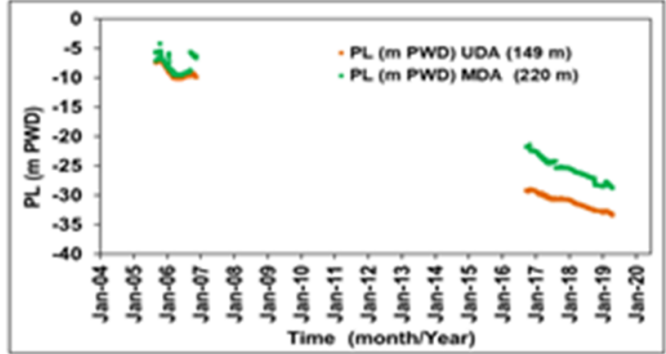

(i) Well ID: DMW-019_Kamrangirchar (U27_M27)

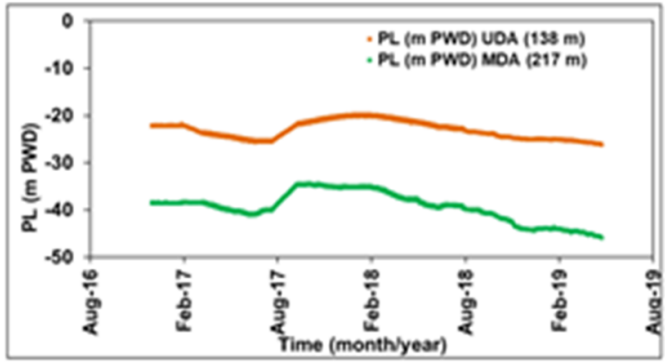

(j) Well ID: DMW-004_Mastul (Patira) (U28_M28)

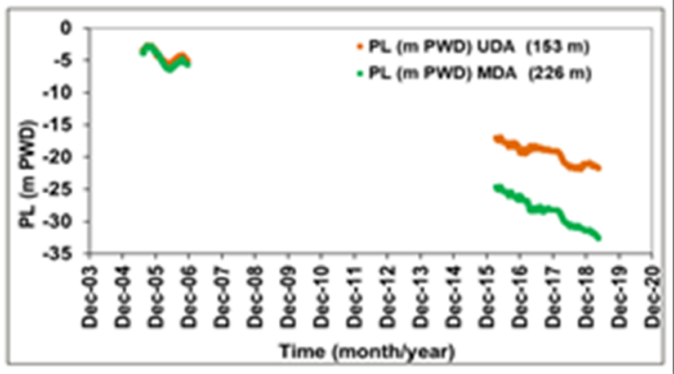

Figure 9. Long-term hydrographs of twin monitoring wells in Dhaka city. (a) Well ID: DMW-009_Khilgaon (U5_M5), (b) Well ID: DMW-017 Khilgaon ( Nasirabad) (U6_M6), (c) Well ID: DMW-006 Mirpur ((U8_M8), (d) Well ID: DMW-007 Banani (U13_M13), (e) Well ID: DMW-010 Gandaria (U20_M20), (f) Well ID: DMW-018 Goranchatbari (U21_M21), (g) Well ID: DMW-005 Beraid (U25_M25), (h) Well ID: DMW-001_Uttarkhan(U26_M26), (i) Well ID: DMW-019_Kamrangirchar (U27_M27), (j) Well ID: DMW-004_Mastul (Patira) (U28_M28). 
In 2018, the PL was -71.24 and $-61.5 \mathrm{~m}$ PWD for UDA and MDA, respectively. The Nasirabad (southeast), Gandaria (south west) and Goranchatbari (central west) twin wells showed linear declines since 2016 but both aquifers' hydrographs were almost coinciding and parallel to each other. In 2018 in Gandaria, the PL was -48.75 and -48.23 m PWD, whereas in Goranchatbari the PL was -40.12 and $-40.32 \mathrm{~m}$ PWD for UDA and MDA, respectively (Figure 9e,f)). Most of the twin hydrographs suggest that the declining rate was higher in MDA than in UDA from 2016 to 2018 (Table 1, Figure 9), not only in the central region but also in the peripheral region (Figure $9 \mathrm{~g}, \mathrm{i}, \mathrm{j})$ ), because in this period the abstraction increased for MDA and decreased for UDA. In 2018, the PL values of Beraid (central east), Mastul (central east) and Kamrangirchar (south west) were observed to be $-32,-20.91$ and $-21.34 \mathrm{~m}$ PWD in UDA, respectively, whereas they were $-36.5,-30.24$ and $-37.60 \mathrm{~m}$ PWD in MDA, respectively. The lowest level of decline in UDA was observed in Mastul (-20.91 $\mathrm{m}$ PWD), and in MDA it was in Uttarkhan (northern) area (-26.76 m PWD) in 2018.

Table 1. The PL values and differences in drawdown in 2018 in twin monitoring wells.

\begin{tabular}{|c|c|c|c|c|c|}
\hline $\begin{array}{l}\text { Twin Well } \\
\text { Id }\end{array}$ & Location & $\begin{array}{c}\text { UDA } \\
\text { PL (m PWD) } 2018\end{array}$ & $\begin{array}{c}\text { MDA } \\
\text { PL (m PWD) } 2018\end{array}$ & $\begin{array}{l}\text { Difference of } \\
\text { Drawdown in } \\
\text { UDA (m/year) } \\
2017-2018\end{array}$ & $\begin{array}{c}\text { Difference of } \\
\text { Drawdown in } \\
\text { MDA (m/year) } \\
2017-2018\end{array}$ \\
\hline DMW-01 & Uttar Khan & -31.92 & -26.76 & 1.66 & 2.6 \\
\hline DMW-02 & Diabari & -40.1 & -33.14 & 3.66 & 2.84 \\
\hline DMW-03 & Khilkhet & -62.12 & -48.56 & 1.82 & 2.43 \\
\hline DMW-04 & Mastul, Patira & -20.91 & -30.24 & 2.35 & 2.13 \\
\hline DMW-05 & Beraid & -31.99 & -36.5 & 0.9 & 0.83 \\
\hline DMW-06 & Mirpur & -62.87 & -56.45 & 2.85 & 4.6 \\
\hline DMW-07 & Banani & -71.24 & -61.48 & 1.51 & 4.97 \\
\hline DMW-08 & Mohammadpur & - & -52.86 & - & 1.53 \\
\hline DMW-09 & Khilgaon & -85.65 & -57.87 & 3.98 & 5.75 \\
\hline DMW-10 & Gandaria & -48.75 & -48.23 & 0.3 & 1.91 \\
\hline DMW-16 & Dakhinkhan & -59.51 & -36.28 & 3.07 & 3.93 \\
\hline DMW-17 & Nasirabad, Khilgaon & -52.14 & -52.25 & 1.6 & 1.6 \\
\hline DMW-18 & Goranchatbari & -40.12 & -40.32 & 2.3 & 2.4 \\
\hline DMW-19 & Kamrangirchar & -21.34 & -37.6 & 0 & 0 \\
\hline
\end{tabular}

\subsection{Piezometric Map Analysis}

5.3.1. Spatial Distribution of Water Table of Shallow Aquifer for 1980

The water table map of the shallow aquifer for 1980 was prepared based on six dug wells with depths from 6.22 to $12.85 \mathrm{~m}$. The highest water table, at $6.0 \mathrm{~m}$ PWD, was found in Sabujbagh and the lowest water table, at $-0.5 \mathrm{~m}$ PWD, was recorded in Mirpur (Figure 10). The highest water table was observed in the highest topographic area toward the south-central region and lowest water table in the lowest topographic area in the direction of the west-central part of the city. The average fluctuations of the water levels of the surrounding rivers (Buriganga, Turag Tongi Khal, Balu and Shitalakhya) of Dhaka city were from 7.2 to $0.8 \mathrm{~m}$ during the wet and dry seasons, respectively, since 1970. The water table and surrounding river water levels are directly correlated to each other. Almost all the dug wells were abandoned or replaced by drilled observation wells after 1984, and this is why the water table map is only available for 1980. Only a few dug wells were monitored, and therefore no isolines were drawn on the map. The water table in shallow aquifers is replenished every year during the monsoon season through the vertical percolation of rainwater [86,87] or floodwater in Bangladesh. In Dhaka city, dug wells are no longer in use because of the scarcity of lifting technology, poor maintenance and inferior water quality [45]. 


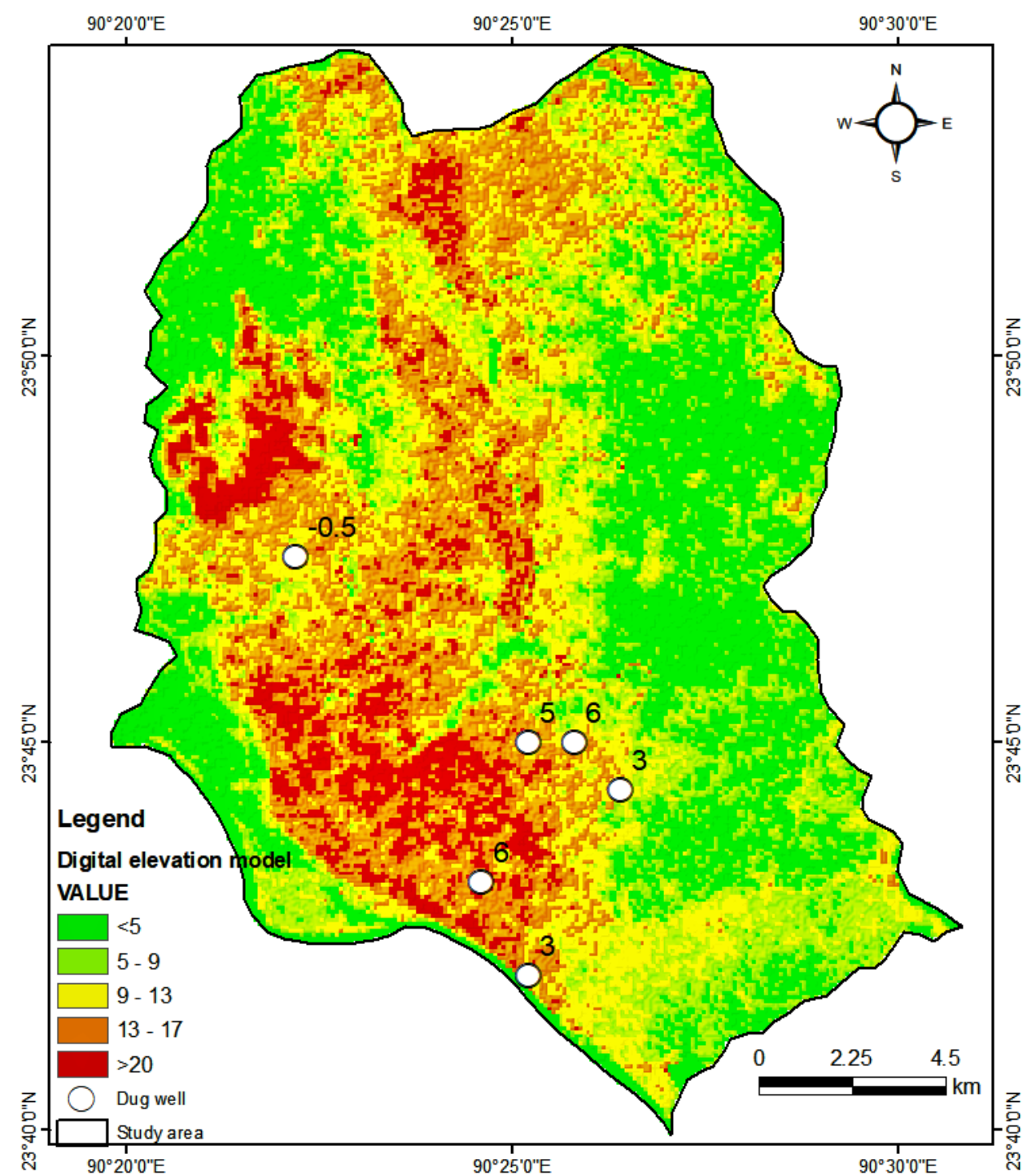

Figure 10. Spatial distribution of dug well water level (m PWD) of shallow aquifer on topographic map [81] for 1980.

\subsubsection{Spatial and Temporal Distribution of Piezometric Level for UDA}

Although groundwater development started for public supply in 1941 in Dhaka $[45,57,88]$, due to the unavailability of piezometric data, it was not possible to make piezometric maps before 1980. The existing extraction of groundwater formed a local cone of depression in 1980. The PL contour of $0 \mathrm{~m}$ follows the outline of the city in that period. The contours of -1 and $-2 \mathrm{~m}$ PWD encompass the local depression due to groundwater pumping. Though PL was very close to the ground surface in the 1980s, a depression of $-3 \mathrm{~m}$ PWD was noted in the south-central part (Motijheel area) of the city (Figure 11a).

The shape, extent and magnitude of the depression cone changed significantly in the year 1990 (Figure 11b). The cone covered a larger area than in the past and the lowest depression was further extended to the southeastern part of the city, in the Sabujbagh area, where the lowest PL was observed at $-17.57 \mathrm{~m}$ PWD. The PL elevation contour $-15 \mathrm{~m}$ PWD covered most of the Sabujbagh and Khilgaon areas, and part of the Motijheel area. The declining trend of PL influenced the south-central part of the city and the influence of the depression was evident laterally up to the northwestern part (Cantonment). In 2000, the magnitude of the depression cone changed dramatically, and a notable change in the PL decline was observed in most parts of the city, except the northeastern part. The 
depression cone extended in a southeast-northwest direction (Mirpur area); the lowest elevation contour at $-45 \mathrm{~m}$ PWD apparently covered the Ramna, Motijheel and Khilgaon areas and the peripheral part of the city was covered by a $-5 \mathrm{~m}$ PWD contour (Figure 11c).

The contour pattern, extent and magnitude of depression were very different in 2010 compared to that observed in 2000. The lowest decline of PL to $-70 \mathrm{~m}$ PWD and the deepest depression cone now developed in the Khilgaon area (Figure 11d). The PL contour of $-60 \mathrm{~m}$ PWD covered the central part of the city, including part of the Cantonment area. A steep piezometric gradient was observed near the Buriganga river. Almost the entire city, including some parts of the northeastern side, experienced a very sharp drop in PL. The PL contour patterns of UDA for 2010 and 2015 are quite similar to each other. The depression cone apparently moved southeastwards, with its peak located in the Khilgaon area in 2015 and the lowest PL was at $-76.25 \mathrm{~m}$ PWD. The PL contour of $-65 \mathrm{~m}$ PWD covered the central part (Figure 11e). The depression contour patterns in 2015 and 2018 are similar to each other, except for the magnitude of the depression cone. The deepest depression contour of $-85 \mathrm{~m}$ PWD was observed in the south-central part and covered the main part of the Khilgaon area. The depression contours of -55 and $-35 \mathrm{~m}$ PWD covered the major part and the peripheral parts of the city, respectively (Figure 11f). The directions of groundwater flow were from the surrounding parts of the city towards its south-central part.
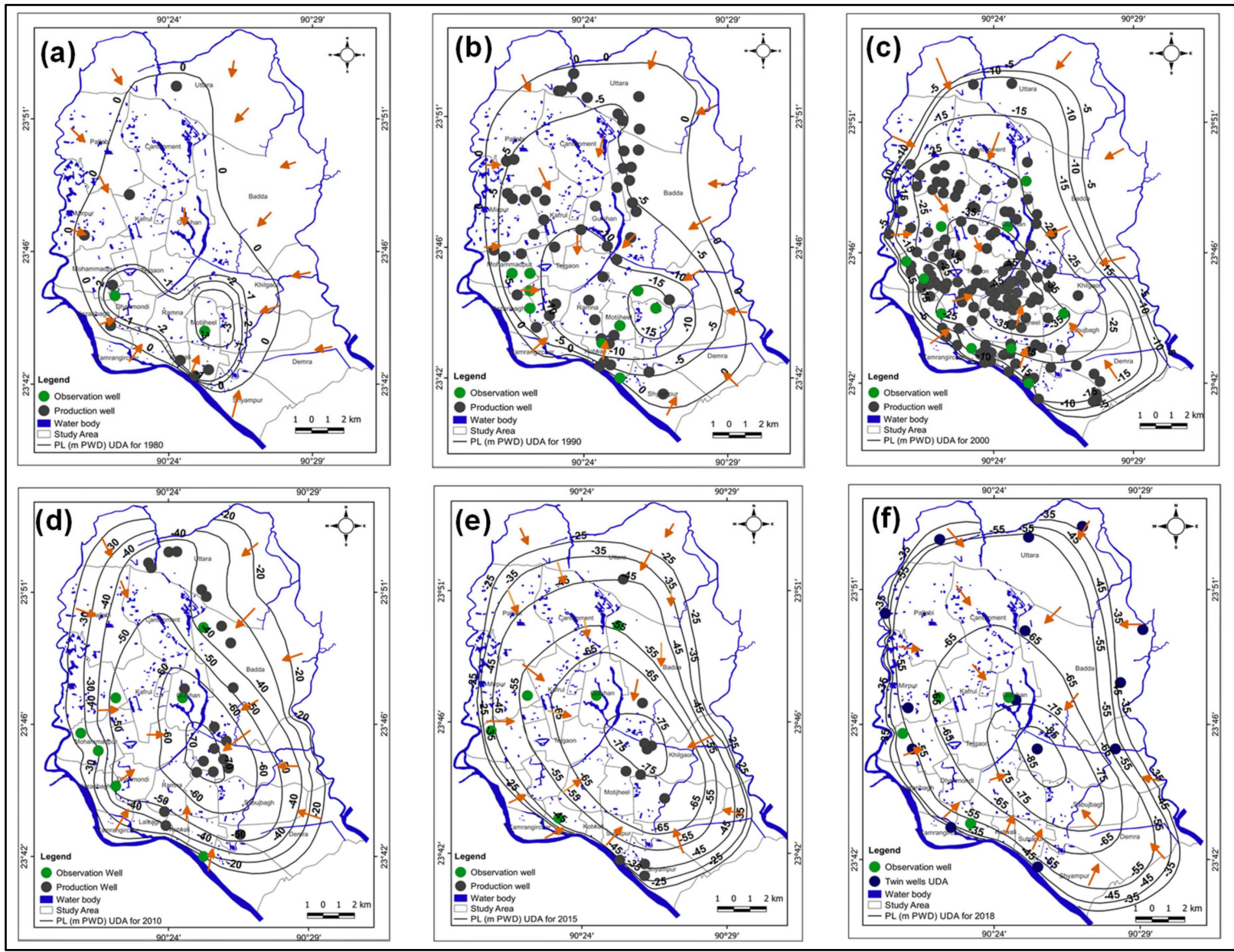

Figure 11. Piezometric maps of Upper Dupi Tila aquifer (UDA) in Dhaka city. (a) 1980, (b) 1990, (c) 2000, (d) 2010, (e) 2015, (f) 2018 . 


\subsubsection{Spatial and Temporal Distribution of Piezometric Level for MDA}

In 2005, the shape and extent of depression showed sporadic patterns and was centered at the DTWs' locations, as the drilling in MDA by DWASA had started in 2004 [80] (Figure 12a). The locations where the depression cones were centered include the Shympur and Sabujbagh areas in the southeast part of the city (-36.82 $\mathrm{m}$ PWD), Mirpur and Pallabi areas in the northwestern part (-34.62 m PWD) and the Dhanmondi area in the southwest part of the city ( $-21.35 \mathrm{~m}$ PWD). The PL contour of $-10 \mathrm{~m}$ PWD covered most parts of the city except the northern extremities. The shape, extent and magnitude of the depression cone changed remarkably in the year 2010 (Figure 12b). The lowest PL elevation at $-68 \mathrm{~m}$ PWD was centered in the central part and mainly covered the Banani and Gulshan areas, and partly covered the Tejgaon, Ramna, Motijheel and Sabujbagh areas. The PL elevation contour of $-25 \mathrm{~m}$ PWD covered most of the city. In 2015, the extent of the depression cone increased compared to 2010 (Figure 12c). The magnitude of the depression was at $-69.61 \mathrm{~m}$ PWD and the areas severely affected by PL decline included the Gulshan, Badda, Khilgaon, Motijheel and Sabujbagh areas. The PL depression contour of $-45 \mathrm{~m}$ PWD covered most of the city. The depression contour pattern for 2016 was similar to that of 2015 but the depression cone extended towards the west-central part of the city (Figure 12c). In 2017, the lowest PL at $-72.76 \mathrm{~m}$ PWD was observed in the southeast part of the city (Manda area) (Figure 12e). Practically, there were no differences in the depression contour patterns for 2018 and 2017, except that the extent of the depression contour $-70 \mathrm{~m}$ PWD was larger in 2018 (Figure 12f). The PL contour of $-35 \mathrm{~m}$ PWD covered the peripheral part of the city. The direction of the groundwater flow was obviously from the peripheral part of the city towards the center of the depression cone in the south-central to the south-eastern part of the city.
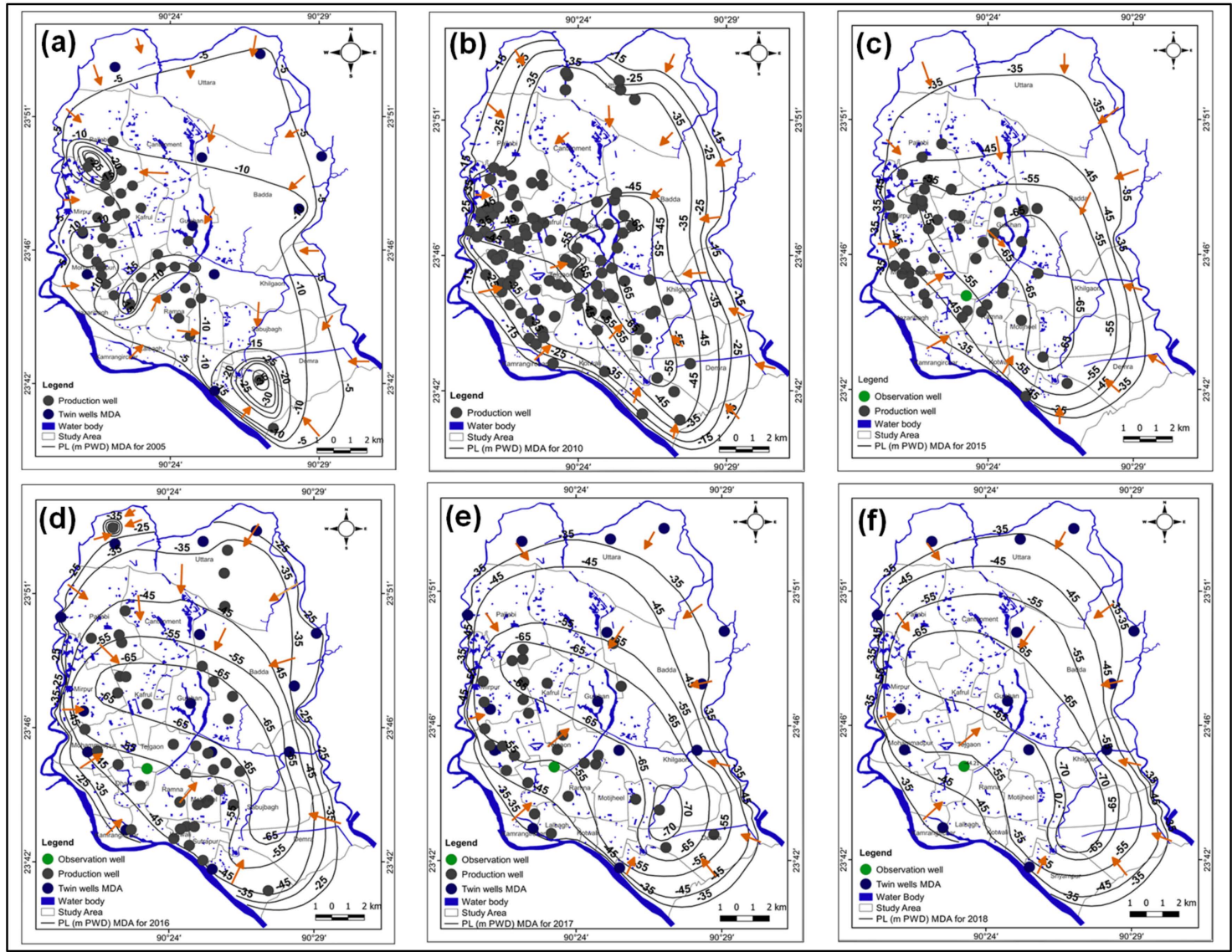

Figure 12. Piezometric maps of Middle Dupi Tila aquifer (MDA) in Dhaka city. (a) 2005, (b) 2010, (c) 2015, (d) 2016, (e) 2017, (f) 2018. 


\section{Discussion}

The analysis of long-term hydrographs and piezometric maps reveals that the pattern and magnitude of the PL decline from the 1980s onward are directly proportional to the population growth associated with the city's expansion (Figure 2) and number of DTWs installed (Figure 6) in particular parts of the city in a certain period. For a better understanding of the trends in PL decline, synthetic graphical overviews of piezometric trends of all the UDA observation wells in Dhaka city were plotted (Figure 13). In these plots, each observation well is plotted as an individual piezometer to observe the evolution of PL. Based on the synthetic graphical overview of the piezometric trends (Figures 13 and 14) and the long-term hydrographs, it is evident that PL is declining at an increasing rate due to abstraction for urban demand. In the 1980s, a local cone with the lowest decline of $-3 \mathrm{~m}$ PWD was observed in the south-central part of the city, in the Motijheel area. The center of the cone shifted towards the southeastern part of the city in 1990, with the maximum depression at $-17.57 \mathrm{~m}$ PWD in the Sabujbagh area. The declining trend laterally extended to the south-central part and the northwestern part of the city.

In 1990, most of the observation wells showed linear decreasing trends, but a very steep declining trend was observed in Dhanmondi (southwestern region) and Motijheel areas. After 1990, most of the piezometers with depths of $30 \mathrm{~m}$ ran dry in the south-central to central regions and also in the southwestern area (Motijheel, Sabujbagh and Mohammadpur) (Figure 8a,b,g). In 2000, the depression cone was marked by the lowest PL elevation at $-49.5 \mathrm{~m}$ PWD in the Ramna and Motijheel areas. Due to population growth in the 1990s and 2000s, the new Dhaka north expanded to its present boundaries in Mohammadpur, Mirpur, Tejgaon, Banani, Baridhara and Uttara $[62,64]$. The massive abstraction by these DTWs caused a PL decline, centered on the area of pumping (Figure 11b), but laterally the area of influence was observed outside of the city before 2000 .

After 2000, most of the observation wells with depths up to $50 \mathrm{~m}$ ran dry in Sabujbagh, Banani, Mirpur and Dhanmondi, except in the northeastern and southwestern areas (e.g., Sutrapur well). Due to the huge PL decline, in 2004 DWASA drilled wells to greater depths than they had previously [80] and installed more than 100 DTWs between 2000 and 2005 both in UDA and MDA [26]. In 2005, most of the observation wells, including twin monitoring wells, declined very sharply and linearly, except for the observation wells in the southwestern region (Lalbagh and Gandaria) (Figure 13). In 2005, a dramatic decline was observed in the entire city due to pumping by the private and DWASA wells. The highest rate of drawdown in UDA ( $5.1 \mathrm{~m} /$ year) was observed in the Mirpur area, followed by a constantly lowering rate. At the same time, in MDA, three sparsely distributed depressions were observed throughout Dhaka city, with the lowest PL elevations of $-36.82 \mathrm{~m}$ PWD in the southeastern part in Shympur and Sabujbagh areas, $-34.62 \mathrm{~m} \mathrm{PWD}$ in the northwestern region in the Mirpur and Pallabi areas, and $-21.35 \mathrm{~m}$ PWD in the Dhanmondi area in the south-central to southwestern part of the city.

Since 2005, the PL has declined more sharply in MDA than in UDA in the central part of the city, as is clearly reflected in the synthetic graphical overviews of the piezometric trends of both aquifers (Figure 14), the twin hydrographs (Figure 9) and the piezometric maps of UDA and MDA (Figures 11 and 12). In 2010, only a few observation wells were working in UDA and these mainly showed both linear and exponential declining trends. In 2010, the depression cone of UDA was marked by the lowest PL contour at $-70 \mathrm{~m}$ PWD in the Khilgaon and Tejgaon areas (Figure 11d). In MDA, the lowest PL at $-68 \mathrm{~m}$ PWD was observed in the central part, which indicated that a very sharp decline of PL occurred in MDA in 2010. A regional depression cone was formed in this aquifer in 2010 and the area of influence included the peripheral parts of the city (Figure 12b). 


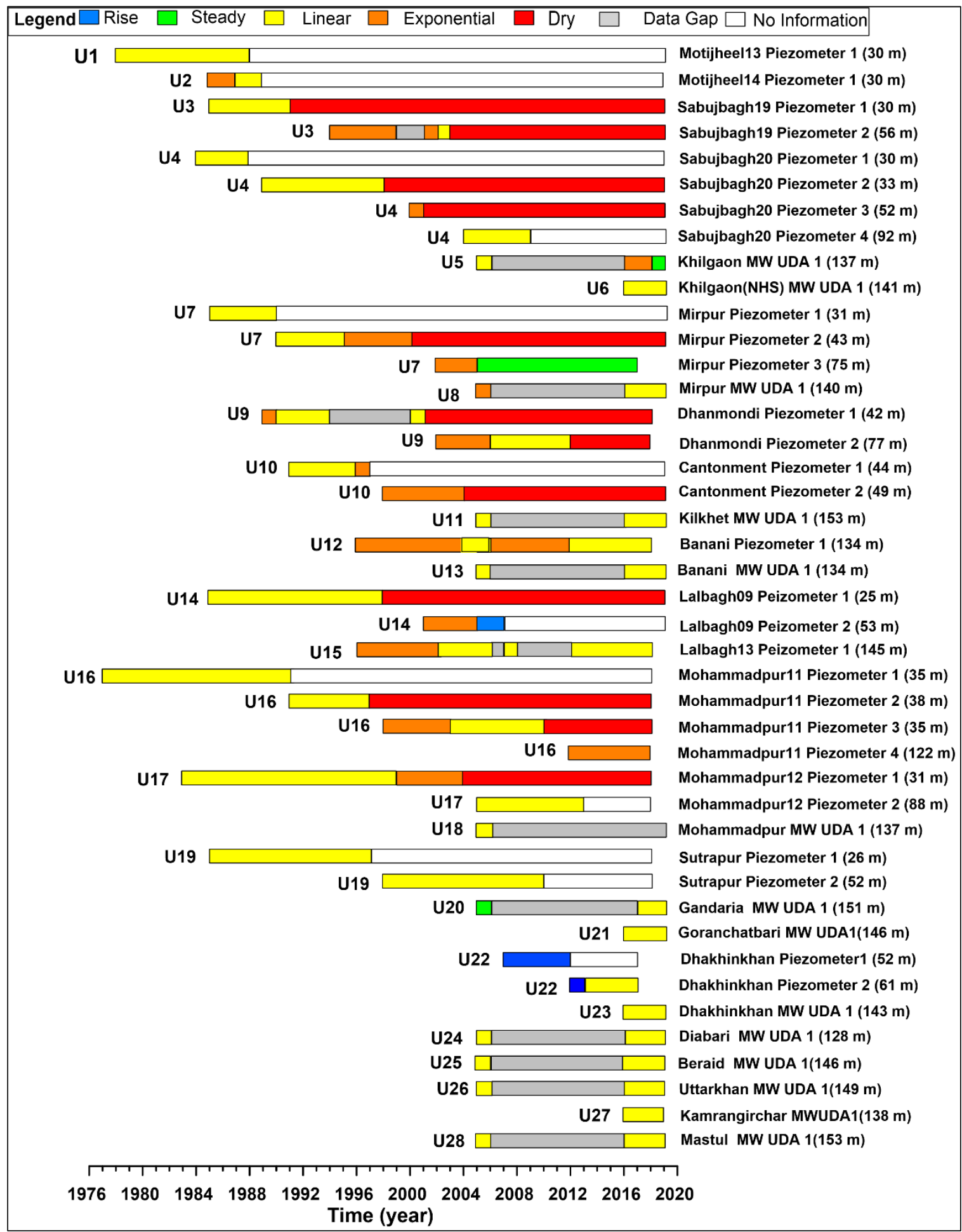

Figure 13. Synthetic graphical overview of piezometric trends of UDA in Dhaka city. Rise (increasing PL), Steady (no PL trend), Linear (declining PL) and Exponential (increasing PL slope) are used to characterize the hydrograph.

From 2015 onwards, most of the observation wells and twin wells showed both linear and exponential falling trends. The lowest PL values in UDA were -76 and $-89 \mathrm{~m}$ PWD, observed in the Khilgaon area in 2015 and 2018, respectively (Figure 11e,f). From 2015 onwards, the entire city experienced a sharp decline in water levels due to massive abstraction because of unplanned urbanization, city expansion and the vast population. In 2015, the center of depression in the MDA was located in the southeast part of the city. 
Since 2016, the cone with the lowest PL contour of $-65 \mathrm{~m}$ PWD extended towards the northwestern part of the city. In 2017 to 2018, the depression contours were similar to each other, but the cone slightly extended from the southeast towards the south-central direction (Figure 12 and Figure 16). Since 2016, the twin wells of the central part and peripheral part of the city showed a sharper drawdown in MDA than UDA due to intensive extraction from MDA (Figures 13 and 14). From 2017 to 2018, the highest rate of decline was observed in the southeast part of the city, in the Khilgaon area, both in UDA (4.0 m/year) and MDA (5.74 m/year) (Figure 9a). The relatively lower drawdown observed in the eastern region in UDA was possible due to lower urbanization and the construction of most of the DTWs in MDA.

The depression cones reflect the pattern of change of groundwater extractions and city expansion in different time periods (Figures 2 and 6). Massive and continuous extraction has modified the directions of groundwater flow by reversing hydraulic gradients towards the central and south-central to southeast parts of the city, where the lowest depression was noticed in both aquifers [89]. The 3D models of both aquifers show the radial flow towards the center of the depression cones in Dhaka city (Figures 15 and 16). These two models illustrate the lateral and vertical spread of depression cones and the peripheral piezometry in the UDA and MDA in Dhaka city.

The consequences of this over-pumping may also prompt environmental hazards like subsidence, negative impacts on water supply, drought and ecological imbalance [14], as well as permanently damaging the aquifers [90]. The vertical recharge of UDA and MDA is very slow, as they are semi-confined aquifers, and lateral flow from the surroundings provides most of the groundwater flow to the depression cone (Figures 15 and 16). For these reasons, the peripheral parts of the city, even the less urbanized parts, also experienced the lowering trend of PL in both aquifers.

The different water balance components of the groundwater reservoir in Dhaka city are indicated in Figure 17. Inflow into the semi-confined Dupi Tila aquifer system in Dhaka city is caused by lateral inflow (L) from the surrounding areas and vertical leakage from the overlying and underlying clay layers. The importance of inflow from the rivers (IR) is governed by the hydraulic resistance between the river and groundwater. Several studies $[41,43,77]$ have postulated direct contact between the river and the aquifer. However, the drilling data we consulted all showed that the upper aquitard is continuous, and this should limit direct infiltration from river water into the semi-confined aquifer. An indirect connection through the aquitard is nevertheless suggested by the steepened gradient of the depression cone in the southwest, near the Buriganga River. Outflow from the Dupi Tila aquifer system in Dhaka city in today's situation occurs fully through pumping $(\mathrm{Q})$. The water balance is then given by:

$$
\text { Lateral inflow }+ \text { Leakage }+ \text { Inflow from Rivers }- \text { Pumping }=\text { Change in Storage }
$$

An estimation of the contribution of the storage decrease to the pumped discharges is given below. In 2020 around 900 million $\mathrm{m}^{3}$ / year was pumped in the study area, which has an area of ca. $358 \mathrm{~km}^{2}$. This accounts for a discharge flux of $2515 \mathrm{~mm} /$ year in 2020. The intensive exploitation of the aquifer started around 40 years ago, and assuming for simplicity a linearly increasing trend in pumping rates, the total discharge flux over the 40 years is around $50,300 \mathrm{~mm}$, or a water column of more than $50 \mathrm{~m}$. During these 40 years, PLs have been lowered systematically. The most recent piezometric maps show that the average PL under the city is now around $60 \mathrm{~m}$ below PWD-deeper in the center of the depression cones, but higher near the rivers, in both the UDA and MDA aquifers. With an average thickness of resp. $98 \mathrm{~m}$ (UDA) and $86 \mathrm{~m}$ (MDA), a total of $184 \mathrm{~m}$, and using an estimated value of $10^{-5} \mathrm{~m}^{-1}$ for the specific elastic storage, the total storativity of the pumped aquifer system will be 0.00184 . The drawdown of $60 \mathrm{~m}$ has thus released a total of ca. $110 \mathrm{~mm}$ of water from storage during the last 40 years. Storage has thus contributed $0.11 / 50=0.2 \%$ of the pumped discharges. The pumped water is thus mainly derived from lateral flow and vertical leakage (part of which is derived from river water). Quantification 
of the relative contribution of both components requires a groundwater model, which we intend to build in the future.

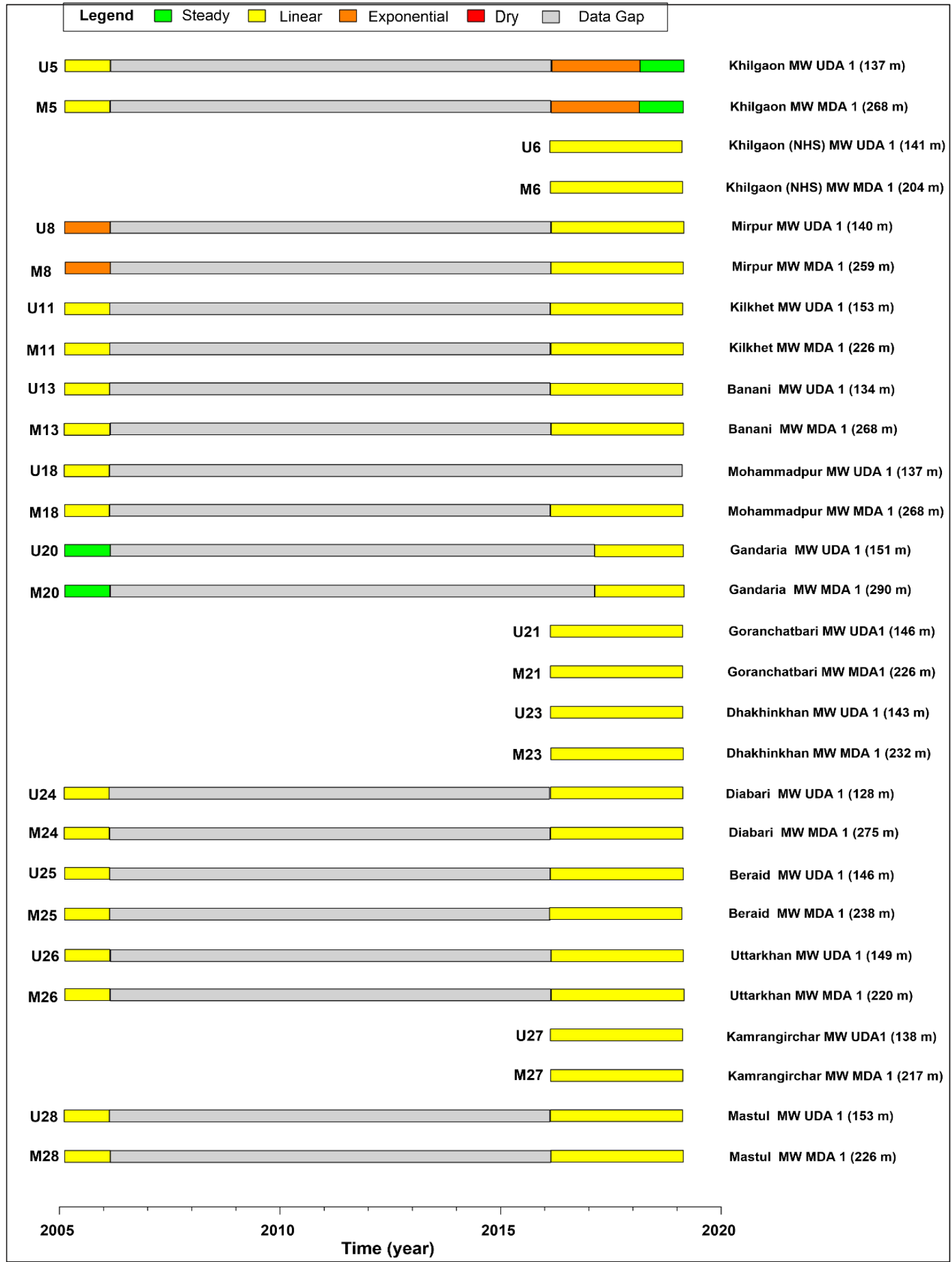

Figure 14. Comparative synthetic graphical overview of piezometric trends of UDA and MDA (twin wells) in Dhaka city. Rise (increasing PL), Steady (no PL trend), Linear (declining PL) and Exponential (increasing PL slope) are used to characterize the hydrograph. 
As only a small fraction $(<1 \%)$ of the pumped groundwater comes from storage, the present piezometric distribution is in a near steady state flow regime and the declining piezometric trend over the last decades is mainly due to a systematic increase in pumping rates and not to depletion of the groundwater storage caused by a lack of inflow. The depth of the depression cones is thus correlated with the abstraction rates.

Rainwater harvesting and the use of treated surface water for different purposes could be good options to reduce groundwater exploitation. Artificial recharge could also be an option to maintain a lasting water supply and to prevent further declines in piezometric levels in the future. Groundwater flow modeling can be used to quantify the water balance components of the aquifer system of Dhaka city, and we recommended that this is done in the future.

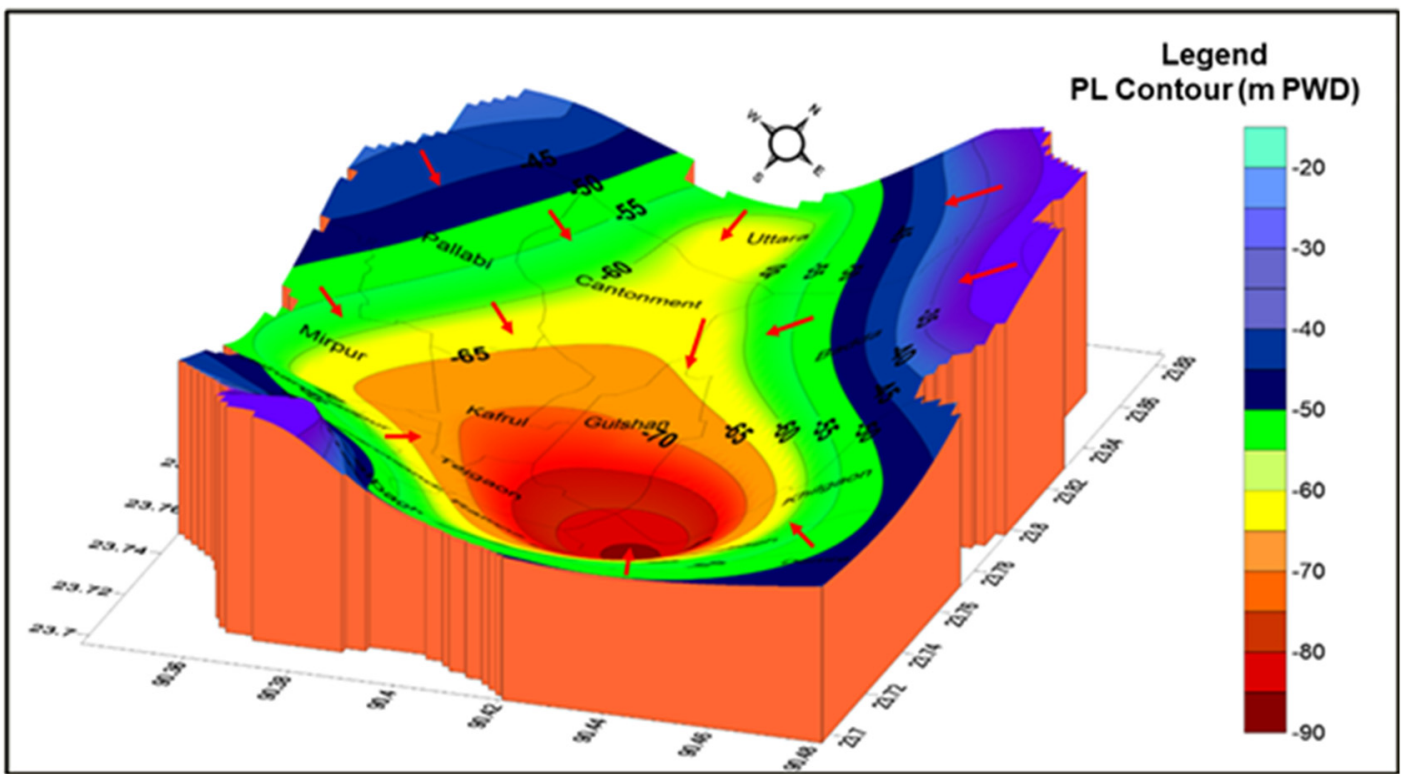

Figure 15. Three-dimensional PL elevation model with water flow directions for 2018 in UDA in Dhaka city.

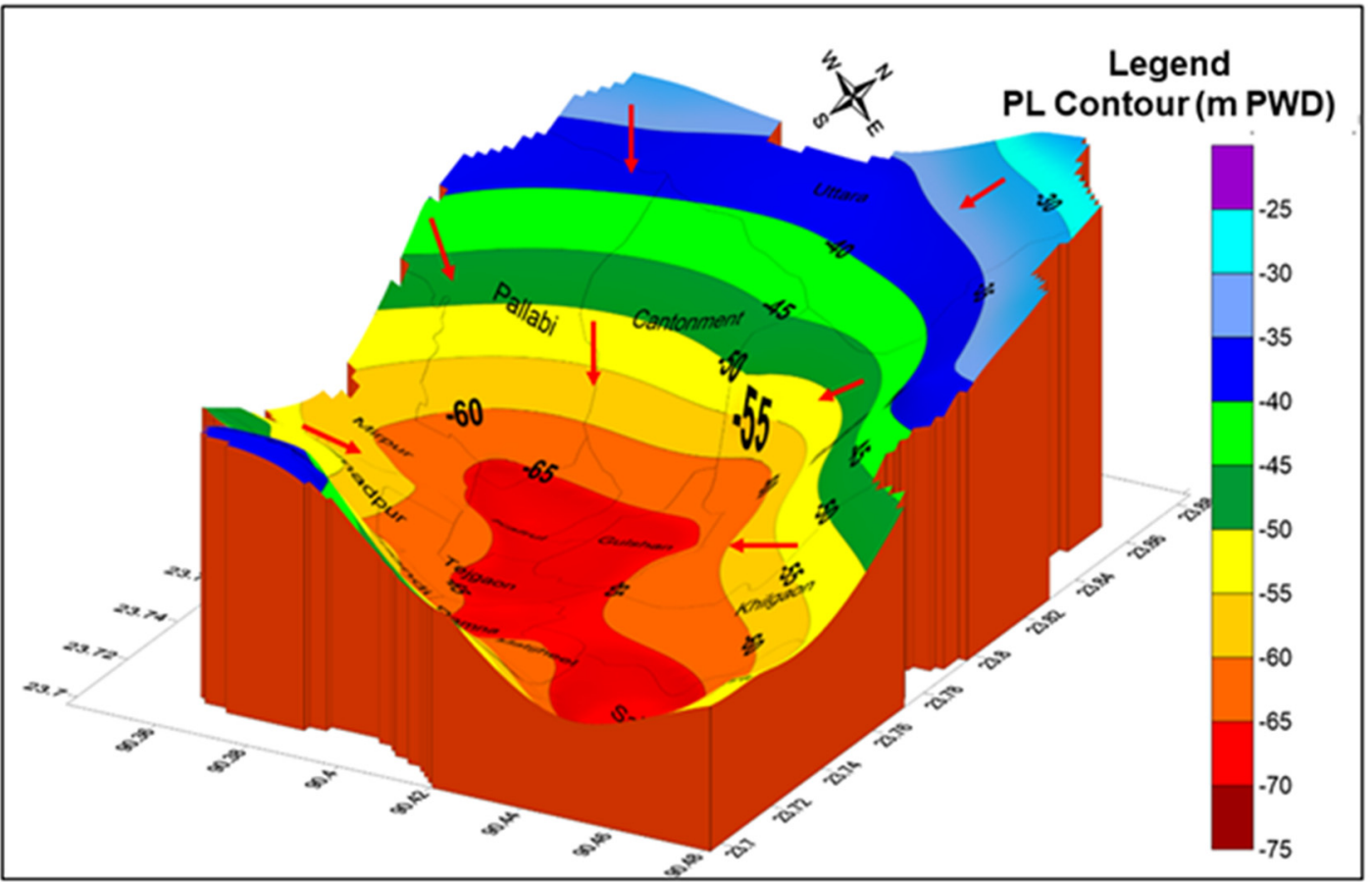

Figure 16. Three-dimensional PL elevation model with water flow directions for 2018 in MDA in Dhaka city. 


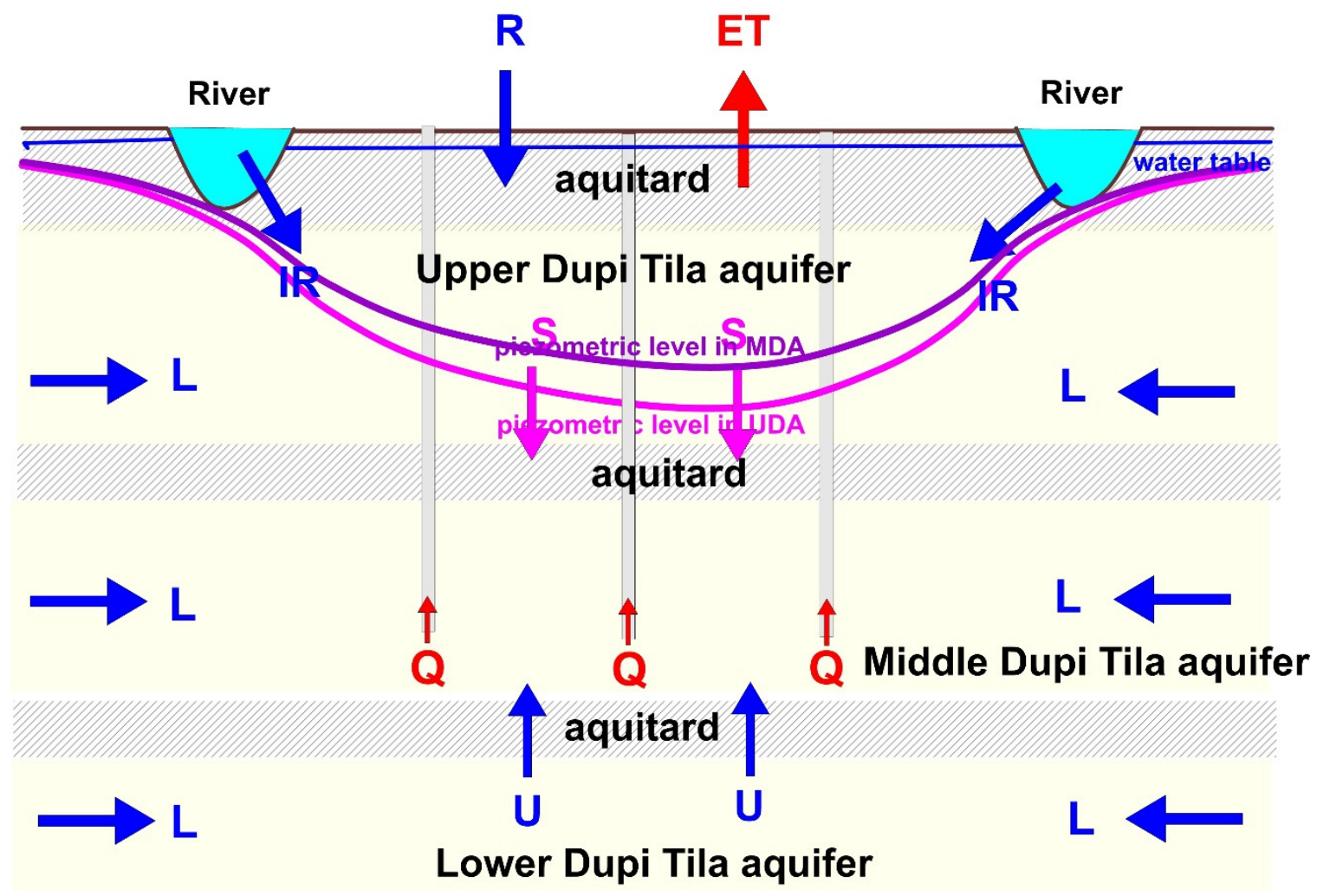

Figure 17. Water balance components of the groundwater reservoir in Dhaka city. $\mathrm{R}=$ Recharge (vertical), ET = Evapotranspiration, $\mathrm{IR}=$ Irrigating, $\mathrm{L}=$ Lateral inflow, $\mathrm{U}=\mathrm{Upward}$ flow, $\mathrm{Q}=$ Pumping, $\mathrm{S}=$ Storage.

\section{Conclusions}

In Dhaka city, hydrogeological data assisted in the delineation of three subsequent semi-confined aquifers (based on lithology) from the surface to the explored depth (463 m): the Upper Dupi Tila Aquifer (UDA), Middle Dupi Tila Aquifer (MDA) and Lower Dupi Tila Aquifer (LDA). The Dupi Tila aquifer system in the study area is a clear example of an overexploited aquifer, shown by continuously declining piezometric levels (PLs). Unplanned urbanization and a vast population increase have altered the natural groundwater dynamics in this city. The documentation of hydraulic heads for both UDA and MDA provides important information for groundwater resource management. The long-term hydrographs and piezometric maps of UDA and MDA provide both temporal and spatial scenarios regarding PL in Dhaka city. The exploitation and supply scenario are closely correlated with population and city expansion for the period from 1963 to 2018. The supplied water consists of more than $78 \%$ groundwater, pumped from DWASA and private wells. A sharp decline in PL values due to large abstraction was observed after 1990 in UDA and after 2005 in MDA. Large amounts of abstraction led to severe lowering of PL in both aquifers in 2010. In 2018, the lowest PL values were -89 and $-70 \mathrm{~m}$ PWD, observed in the south-central part of the city, in UDA and MDA, respectively. In the center of the depression cone in 2018, the average rate of decline was $4.0 \mathrm{~m}$ /year in UDA and 5.74 $\mathrm{m}$ /year in MDA; the average rate of decline in the entire city was $2.25 \mathrm{~m} /$ year in UDA and $2.8 \mathrm{~m} /$ year in MDA. If the PL decline continues at this rate in the future, this will deplete the aquifers. Huge and prolonged extraction have changed the flow directions of groundwater in both aquifers by reversing hydraulic gradients towards the central and south-central to southeastern parts of the city, where the peaks of the depression cones were observed in both aquifers. The long-term development and management of groundwater resources warrants comprehensive and multi-objective approaches that must include the cost-effectiveness of overexploitation and sustainability. In order to addressing 
sustainability, a long-term management plan that includes the management of unplanned urbanization, population migration or control of growth and decentralization of industrial and economic zones is urgently needed, otherwise the situation may go beyond our control.

Author Contributions: Conceptualization, M.I. and K.W.; Methodology, M.I. and K.W.; Software, M.I., M.M.R.S. and M.V.C.; Data curation, M.I., S.K. and M.M.R.S.; Resource, M.I., S.K.; Formal analysis, M.I., M.V.C., M.M.R.S. and K.W.; Funding acquisition, M.I.; Writing—original draft preparation, M.I.; Writing-review \& editing, M.I., M.V.C., D.H. and K.W.; Supervision, K.W. All authors have read and agreed to the published version of the manuscript.

Funding: This research was funded by Islamic Development Bank (IDB) (grant number 600032960).

Institutional Review Board Statement: Not applicable.

Informed Consent Statement: Not applicable.

Data Availability Statement: The data presented in this study are available on request from the corresponding author.

Acknowledgments: The first author (MI) is grateful to the Islamic Development Bank (IDB) for financing this research. The authors express thanks to the authority of BWDB and DWASA for providing access to the data used. The authors extend special thanks to Anwar Zahid, Director, BWDB, for valuable support and cooperation. The authors would like to thank the anonymous reviewers for their comments and suggestions in improving the quality of the manuscript.

Conflicts of Interest: The authors declare no conflict of interest.

\section{References}

1. Hoque, M.A.; Hoque, M.M.; Ahmed, K.M. Declining groundwater level and aquifer dewatering in Dhaka metropolitan area, Bangladesh: Causes and quantification. Hydrogeol. J. 2007, 15, 1523-1534. [CrossRef]

2. Long, D.; Yang, W.; Scanlon, B.R.; Zhao, J.; Liu, D.; Burek, P.; Pan, Y.; You, L.; Wada, Y. South-to-North Water Diversion stabilizing Beijing's groundwater levels. Nat. Commun. 2020, 11, 1-10. [CrossRef] [PubMed]

3. Zhou, Y.; Dong, D.; Liu, J.; Li, W. Upgrading a regional groundwater level monitoring network for Beijing Plain, China. Geosci. Front. 2013, 4, 127-138. [CrossRef]

4. Naik, P.K.; Tambe, J.A.; Dehury, B.N.; Tiwari, A.N. Impact of urbanization on the groundwater regime in a fast growing city in central India. Environ. Monit. Assess. 2008, 146, 339-373. [CrossRef] [PubMed]

5. Qureshi, A.S.; McCornick, P.G.; Sarwar, A.; Sharma, B.R. Challenges and prospects of sustainable groundwater management in the Indus Basin, Pakistan. Water Resour. Manag. 2010, 24, 1551-1569. [CrossRef]

6. Rodell, M.; Velicogna, I.; Famiglietti, J.S. Satellite-based estimates of groundwater depletion in India. Nature 2009, 460, 999-1002. [CrossRef]

7. Urrutia, J.; Jódar, J.; Medina, A.; Herrera, C.; Chong, G.; Urqueta, H.; Luque, J.A. Hydrogeology and sustainable future groundwater abstraction from the Agua Verde aquifer in the Atacama Desert, northern Chile. Hydrogeol. J. 2018, 26, $1989-2007$. [CrossRef]

8. Famiglietti, J.S.; Lo, M.; Ho, S.L.; Bethune, J.; Anderson, K.; Syed, T.H.; Swenson, S.C.; de Linage, C.R.; Rodell, M. Satellites measure recent rates of groundwater depletion in California's Central Valley. Geophys. Res. Lett. 2011, 38, L03403. [CrossRef]

9. Longuevergne, L.; Scanlon, B.R.; Wilson, C.R. GRACE Hydrological estimates for small basins: Evaluating processing approaches on the High Plains Aquifer, USA. Water Resour. Res. 2010, 46, W11517. [CrossRef]

10. Voss, K.A.; Famiglietti, J.S.; Lo, M.; De Linage, C.; Rodell, M.; Swenson, S.C. Groundwater depletion in the Middle East from GRACE with implications for transboundary water management in the Tigris-Euphrates-Western Iran region. Water Resour. Res. 2013, 49, 904-914. [CrossRef]

11. Werner, A.D.; Zhang, Q.; Xue, L.; Smerdon, B.D.; Li, X.; Zhu, X.; Yu, L.; Li, L. An initial inventory and indexation of groundwater mega-depletion cases. Water Resour. Manag. 2013, 27, 507-533. [CrossRef]

12. Van Camp, M.; Walraevens, K. Recovery scenarios for deep over-exploited aquifers with limited recharge: Methodology and application to an aquifer in Belgium. Environ. Geol. 2009, 56, 1505-1516. [CrossRef]

13. Mays, L.W. Groundwater resources sustainability: Past, present, and future. Water Resour. Manag. 2013, 27, 4409-4424. [CrossRef]

14. Konikow, L.F.; Kendy, E. Groundwater depletion: A global problem. Hydrogeol. J. 2005, 13, 317-320. [CrossRef]

15. Chaussard, E.; Wdowinski, S.; Cabral-Cano, E.; Amelung, F. Land subsidence in central Mexico detected by ALOS InSAR time-series. Remote Sens. Environ. 2014, 140, 94-106. [CrossRef]

16. Novelo, J.A.M.; Tapia, L.R. The growth of water demand in Mexico City and the over-exploitation of its aquifers. In Water resources in Mexico; Springer: Berlin/Heidelberg, Germany, 2012; pp. 395-406.

17. Scanlon, B.R.; Faunt, C.C.; Longuevergne, L.; Reedy, R.C.; Alley, W.M.; McGuire, V.L.; McMahon, P.B. Groundwater depletion and sustainability of irrigation in the US High Plains and Central Valley. Proc. Natl. Acad. Sci. USA 2012, 109, 9320-9325. [CrossRef] 
18. Doell, P.; Mueller Schmied, H.; Schuh, C.; Portmann, F.T.; Eicker, A. Global-scale assessment of groundwater depletion and related groundwater abstractions: Combining hydrological modeling with information from well observations and GRACE satellites. Water Resour. Res. 2014, 50, 5698-5720. [CrossRef]

19. Wada, Y.; Wisser, D.; Bierkens, M.F. Global modeling of withdrawal, allocation and consumptive use of surface water and groundwater resources. Earth Syst. Dyn. Discuss. 2014, 5, 15-40. [CrossRef]

20. Chen, M.; Tomás, R.; Li, Z.; Motagh, M.; Li, T.; Hu, L.; Gong, H.; Li, X.; Yu, J.; Gong, X. Imaging land subsidence induced by groundwater extraction in Beijing (China) using satellite radar interferometry. Remote Sens. 2016, 8, 468. [CrossRef]

21. Gleeson, T.; VanderSteen, J.; Sophocleous, M.A.; Taniguchi, M.; Alley, W.M.; Allen, D.M.; Zhou, Y. Groundwater sustainability strategies. Nat. Geosci. 2010, 3, 378-379. [CrossRef]

22. Condon, L.E.; Maxwell, R.M. Simulating the sensitivity of evapotranspiration and streamflow to large-scale groundwater depletion. Sci. Adv. 2019, 5, eaav4574. [CrossRef]

23. Mendonça, B.; Sandwell, D. Satellite Interferometric Investigations of Subsidence Events Associated with Groundwater Extraction in Sao Paulo, Brazil. Int. J. Geol. Environ. Eng. 2016, 10, 127-133.

24. Van Camp, M.; Radfar, M.; Walraevens, K. Assessment of groundwater storage depletion by overexploitation using simple indicators in an irrigated closed aquifer basin in Iran. Agric. Water Manag. 2010, 97, 1876-1886. [CrossRef]

25. Bangladesh Bureau of Statistics (BBS). Statistical Yearbook of Bangladesh, Bangladesh Bureau of Statistics (BBS); Ministry of Planning, Government of People's Republic of Bangladesh: Dhaka, Bangladesh, 2011.

26. Dhaka Water Supply and Sewerage Authority (DWASA). Annual Report (2018-2019); DWASA: Dhaka, Bangladesh, 2018. Available online: https:/ / dwasa.org.bd/annual-reports/ (accessed on 30 August 2020).

27. Khan, M.R.; Koneshloo, M.; Knappett, P.S.; Ahmed, K.M.; Bostick, B.C.; Mailloux, B.J.; Mozumder, R.H.; Zahid, A.; Harvey, C.F.; Van Geen, A. Megacity pumping and preferential flow threaten groundwater quality. Nat. Commun. 2016, 7, 1-8. [CrossRef] [PubMed]

28. Knappett, P.; Mailloux, B.; Choudhury, I.; Khan, M.; Michael, H.; Barua, S.; Mondal, D.; Steckler, M.; Akhter, S.; Ahmed, K. Vulnerability of low-arsenic aquifers to municipal pumping in Bangladesh. J. Hydrol. 2016, 539, 674-686. [CrossRef]

29. Lyu, H.-M.; Shen, S.-L.; Wu, Y.-X.; Zhou, A.-N. Calculation of groundwater head distribution with a close barrier during excavation dewatering in confined aquifer. Geosci. Front. 2021, 12, 791-803. [CrossRef]

30. Ahmed, K. Dupi Tila Aquifer of Dhaka: Hydraulic and Hydrochemical Response to Extensive Exploitation; Groundwater in the Urban Environment: Selected City Profiles; IAH: London, UK, 1999; Volume 21, pp. 19-30.

31. Konikow, L.F. Contribution of global groundwater depletion since 1900 to sea-level rise. Geophys. Res. Lett. 2011, 38, L18601. [CrossRef]

32. Gleeson, T.; Wada, Y.; Bierkens, M.F.; Van Beek, L.P. Water balance of global aquifers revealed by groundwater footprint. Nature 2012, 488, 197-200. [CrossRef] [PubMed]

33. Alley, W.M.; Reilly, T.E.; Franke, O.L. Sustainability of Ground-Water Resources; US Department of the Interior, US Geological Survey: Sunrise Valley Drive Reston, VA, USA, 1999; Volume 1186.

34. Hiscock, K.M.; Rivett, M.O.; Davison, R.M. Sustainable groundwater development. Geol. Soc. Lond. Spec. Publ. 2002, 193, 1-14. [CrossRef]

35. Council of Canadian Academies. The Sustainable Management of Groundwater in Canada; Expert Panel on Groundwater, Report to the Government of Canada; Ministry of Industry: Ottawa, ON, Canada, 2009.

36. Lóaiciga, H.A.; Leipnik, R.B. Theory of sustainable groundwater management: An urban case study. Urban Water 2001, 3, 217-228. [CrossRef]

37. Loáiciga, H.A. Sustainable groundwater management: The theory of a game. In Critical Transitions in Water and Environmental Resources Management; Amer Society of Civil Engineers: Reston, VA, USA, 2004; pp. 1-10.

38. McMahon, P.; Plummer, L.; Böhlke, J.; Shapiro, S.; Hinkle, S. A comparison of recharge rates in aquifers of the United States based on groundwater-age data. Hydrogeol. J. 2011, 19, 779. [CrossRef]

39. URSS. World Water Balance and Water Resources of the Earth; UNESCO: Paris, France, 1978.

40. Van Bracht, M. Made to Measure: Information Requirements and Groundwater Level Monitoring Networks. Ph.D. Thesis, Vrije Universiteit Amsterdam, Amsterdam, The Netherlands, 2001.

41. Hasan, M. The Vulnerability of the Dupi Tila Aquifer. Dhaka, Bangladesh. Ph.D. Thesis, University College London, University of London, London, UK, 1999, unpublished.

42. Darling, W.; Burgess, W.; Hasan, M. Isotopic Evidence for Induced River Recharge to the Dupi Tila Aquifer in the Dhaka Urban Area, Bangladesh; (IAEA-TECDOC-1298); International Atomic Energy Agency (IAEA): Vienna, Austria, 2002.

43. Morris, B.L.; Seddique, A.A.; Ahmed, K.M. Response of the Dupi Tila aquifer to intensive pumping in Dhaka, Bangladesh. Hydrogeol. J. 2003, 11, 496-503. [CrossRef]

44. Akther, H.; Ahmed, M.; Rasheed, K. Spatial and temporal analysis of groundwater level fluctuation in Dhaka city, Bangladesh. Asian J. Earth Sci. 2009, 2, 49-57. [CrossRef]

45. Ahmed, K.M.; Islam, M.S.; Sultana, S.; Ahmed, S.; Rabbani, G. Changes in the Groundwater Regime of Dhaka City: A Historical Perspective; Environment of Capital Dhaka-Plants Wildlife Gardens Parks Air Water Earthquake; Asiatic Society of Bangladesh: Dhaka, Bangladesh, 2011; pp. 383-400. 
46. Shamsudduha, M.; Taylor, R.G.; Ahmed, K.M.; Zahid, A. The impact of intensive groundwater abstraction on recharge to a shallow regional aquifer system: Evidence from Bangladesh. Hydrogeol. J. 2011, 19, 901-916. [CrossRef]

47. Rahman, M.A.; Wiegand, B.A.; Badruzzaman, A.; Ptak, T. Hydrogeological analysis of the upper Dupi Tila Aquifer, towards the implementation of a managed aquifer-recharge project in Dhaka City, Bangladesh. Hydrogeol. J. 2013, 21, 1071-1089. [CrossRef]

48. Hoque, M.; McArthur, J.; Sikdar, P.; Ball, J.; Molla, T. Tracing recharge to aquifers beneath an Asian megacity with Cl/Br and stable isotopes: The example of Dhaka, Bangladesh. Hydrogeol. J. 2014, 22, 1549-1560. [CrossRef]

49. Wu, Y.-X.; Lyu, H.-M.; Han, J.; Shen, S.-L. Dewatering-induced building settlement around a deep excavation in soft deposit in Tianjin, China. J. Geotech. Geoenviron. Eng. 2019, 145, 05019003. [CrossRef]

50. Wu, Y.-X.; Shen, S.-L.; Lyu, H.-M.; Zhou, A. Analyses of leakage effect of waterproof curtain during excavation dewatering. J. Hydrol. 2020, 583, 124582. [CrossRef]

51. Shen, S.-L.; Lyu, H.-M.; Zhou, A.; Lu, L.-H.; Li, G.; Hu, B.-B. Automatic control of groundwater balance to combat dewatering during construction of a metro system. Autom. Constr. 2021, 123, 103536. [CrossRef]

52. Quayyum, S.; Rahman, M.M.; Mohsin, M. Sustainable Water Supply in Dhaka City: Present \& Future. In Proceedings of the Asian Science and Technology Seminar, Thailand, Bangkok, Thailand, 10-11 March 2008.

53. Monsur, M. Stratigraphical and palaeomagnetical studies of some quaternary deposits of the Bengal Basin, Bangladesh. Ph.D. Thesis, Vrije University, Brussels, Belgium, 1990; p. 241, unpublished.

54. Morgan, J.P.; McIntire, W.G. Quaternary geology of the Bengal basin, East Pakistan and India. Geol. Soc. Am. Bull. 1959, 70, 319-342. [CrossRef]

55. Islam, N. DHAKA: From City to Megacity: Perspectives on People, Places; Planning and Development Issues; University of Dhaka: Dhaka, Bangladesh, 1996.

56. Mowla, Q.A. Review of Dhaka structure plan 2016-2035; Official Report Submitted to RAJUK; RAJUK: Dhaka, Bangladesh, 2015.

57. Ahmed, B.; Hasan, R.; Maniruzzaman, K. Urban morphological change analysis of Dhaka city, Bangladesh, using space syntax. ISPRS Int. J. Geo-Inf. 2014, 3, 1412-1444. [CrossRef]

58. Chowdhury, A.; Faruqui, S. Physical growth of Dhaka city. In Dhaka: Past, Present and Future; Asiatic Society of Bangladesh: Dhaka, Bangladesh, 1989; pp. 43-61.

59. Chowdhury, A.M. Dhaka, 2nd ed.; Asiatic Society of Bangladesh: Dhaka, Bangladesh, 2012.

60. Hassan, M.M.; Southworth, J. Analyzing land cover change and urban growth trajectories of the mega-urban region of Dhaka using remotely sensed data and an ensemble classifier. Sustainability 2018, 10, 10. [CrossRef]

61. Hossain, S. Social Formations of the Megacity of Dhaka: A Review Essay; Elsevier: Amsterdam, The Netherlands, 2013.

62. Kabir, A.; Parolin, B. Planning and development of Dhaka-A story of 400 years. In Proceedings of the 15th International Planning History Society Conference, San Paulo, Brazil, 15-18 July 2012.

63. Mahtab-uz-Zaman, Q.; Lau, S.S. City expansion policy versus compact city demand: The case of Dhaka. In The Compact Cities: Sustainable Urban Form for Developing Countries; Jenks, M., Burgess, R., Eds.; Springer: Berlin/Heidelberg, Germany, 2000; pp. $141-1152$.

64. Uddin, A.S.; Mohuya, F.A. Growth and Development of Dhaka North: 1971-2011. J. Asiat. Soc. Bangladesh (Hum.) 2013, 58, 303-334.

65. Huq, S.; Alam, M. Flood management and vulnerability of Dhaka City. In Building Safer Cities; World Bank Publications: Washington, DC, USA, 2003; p. 121.

66. Talukder, S.H. Managing Megacities: A Case Study of Metroplitan Regional Governance for Dhaka; Murdoch University: Murdoch, Australia, 2006.

67. Islam, N. Dhaka Now: Contemporary Urban Development Bangladesh Geographical Society Dhaka; Bangladesh Geographical Society: Dhaka, Bangladesh, 2005.

68. Kamal, A.M.; Midorikawa, S. GIS-based geomorphological mapping using remote sensing data and supplementary geoinformation: A case study of the Dhaka city area, Bangladesh. Int. J. Appl. Earth Obs. Geoinf. 2004, 6, 111-125. [CrossRef]

69. Asian Disaster Preparedness Centre (ADPC). Engineering Geological Map for Seismic Hazard and Vulnerability Assessment of Dhaka, Chittagong and Sylhet City Corporation Area, OYO International Corporation; CDMP: Dhaka, Bangladesh, 2009.

70. EPC/MMP. Dhaka Region Groundwater and Subsidence Study, Report Prepared by Engineering and Planning Consultants in Association with Sir M. MacDonald and Partners Ltd. (UK) for Dhaka WASA; DWASA: Dhaka, Bangladesh, 1991.

71. Aggarwal, P.K.; Froehlich, K.; Basu, A.; Poreda, R.; Kulkarni, K.; Tarafdar, S.; Mohamed, A.; Nasir, A.; Alamgir, H.; Mizanur, R. A Report on Isotope Hydrology of Groundwater in Bangladesh: Implications for Characterization and Mitigation of Arsenic in Groundwater; International Atomic Energy Agency: Vienna, Austria, 2000.

72. Davies, J.; Exley, C. Short Term BGS Pilot Project to Assess the Hydrochemical Character of the Main Aquifer Units of the Central and North-Eastern Bangladesh and Possible Toxicity of Groundwater to Fish and Humans: Appendices 1-5; British Geological Survey: Keyworth, UK, 1992.

73. Khandoker, R. Origin of elevated Barind-Madhupur areas, Bengal basin: Result of neotectonic activities. Bangladesh J. Geol. 1987, 6, 1-9.

74. Maitra, M.K.; Akhter, S. Neotectonics in Madhupur tract its surroundings floodplains. Dhaka Univ. J. Earth Environ. Sci. 2011, 12, 83-89. 
75. Davies, J. The Pilot Study into Optimum Well Design: IDA 4000 Deep Tube Well II Project. Volume 2: The Geology of the Alluvial Aquifers of Central Bangladesh; British Geology Survey Technical Report WD/89/9.; British Geological Survey: Keyworth, UK, 1989.

76. BGS; DPHE. Arsenic Contamination of Groundwater in Bangladesh; British Geological Survey Technical Report, WC/00/19. 4 Volumes; British Geological Survey: Keyworth, UK, 2001.

77. Islam, M.B.; Firoz, A.; Foglia, L.; Marandi, A.; Khan, A.R.; Schüth, C.; Ribbe, L. A regional groundwater-flow model for sustainable groundwater-resource management in the south Asian megacity of Dhaka, Bangladesh. Hydrogeol. J. 2017, 25, 617-637. [CrossRef]

78. Gani, M.R.; Alam, M.M. Fluvial facies architecture in small-scale river systems in the Upper Dupi Tila Formation, northeast Bengal Basin, Bangladesh. J. Asian Earth Sci. 2004, 24, 225-236. [CrossRef]

79. Iqbal Hossain, M. Evaluation of Aquifer Characteristics of Dhaka City Using Pumped Well Data. Master's Thesis, Water Resources Engineering (WRE). BUET, Dhaka, Bangladesh, 1997.

80. DWASA; IWM. Resource Assessment and Monitoring of Water Supply Sources for Dhaka City. Final Report on Resource Assessment; Dhaka Water Supply and Sewerage Authority (DWASA): Dhaka, Bangladesh, 2006; Main Report; Volume I.

81. Available online: https:/ / earthexplorer.usgs.gov/ (accessed on 15 January 2020).

82. Ralhan, O.P. The Great Gurus of the Sikhs; Anmol Publications PVT. LTD.: Anmol, India, 2002; 1678p, ISBN1 -10:8174884793. ISBN2 -13:978-8174884794.

83. DWASA; IWM. Establishment of Groundwater Monitoring system in Dhaka City for Aquifer System and DWASA Production Wells; DWASA: Dhaka, Bangladesh, 2016.

84. Bangladesh Water Development Board (BWDB). Effects of Overwithdrawal of Groundwater in Dhaka City; BWDB Water Supply Paper 519, Groundwater Circle-II; BWDB: Dhaka, Bangladesh, 1991.

85. Bangladesh Bureau of Statistics (BBS). Bangladesh Population Census. Field Report of Different Upazilas of Dhaka District; Statistics and Informatics Division (SID); Ministry of Planning: Dhaka, Bangladesh, 2001.

86. Ahmed, K.; Burgess, W. Surface Water and Groundwater Interaction in Bangladesh Hydrogeology; Groundwater Resources and Development in Bangladeshbackground to the Arsenic Crisis, Agricultural Potential and the Environment, AA Rahman, P. Ravenscroft; et al., Bangladesh Centre for Advanced Studies; University Press Ltd.: Dhaka, Bangladesh, 2003.

87. Ravenscroft, P. Overview of the Hydrogeology of Bangladesh. Groundwater Resources and Development in Bangladesh-Background to the Arsenic Crisis, Agricultural Potential and the Environment; University Press Ltd.: Dhaka, Bangladesh, 2003.

88. Khan, T.A. Dhaka Water Supply and Sewerage Authority: Performance and Challenges; DWASA Report; DWASA: Dhaka, Bangladesh, 2013.

89. Islam, M.; Van Camp, M.; Hossain, D.; Sarker, M.M.R.; Khatun, S.; Walraevens, K. The Impact of Urbanization and Rapid Population Growth on the Groundwater Regime in Dhaka City, Bangladesh; Copernicus Meetings: Göttingen, Germany, 2021.

90. Custodio, E. Aquifer overexploitation: What does it mean? Hydrogeol. J. 2002, 10, 254-277. [CrossRef] 